\title{
ENTRE NOVELA Y TEATRO: EL DISCURSO DE MESONERO ROMANOS SOBRE LOS ARTÍCULOS DE COSTUMBRES EN EL MARCO DE LA TRANSFORMACIÓN MODERNA DEL CONCEPTO DE IMITACIÓN
}

\author{
ANTONIO FERRAZ MARTíNeZ \\ Madrid
}

1. REVAlORIZACiÓN CRÍtiCA DEL COSTUMBRISMO: LA MÍMESIS COSTUMBRISTA

Uno de los casos más claros de renovación en la historiografía literaria española es, sin duda alguna, el de la revalorización crítica del costumbrismo. Como botón de muestra, remito al monográfico que, en enero del 2000 , le consagró Ínsula bajo el lema «Reivindicar el costumbrismo». Esclarecedor también era el título — «Acreditar el costumbrismo»- con que abría ese número Joaquín Álvarez Barrientos ${ }^{1}$.

No quiero dejar de resaltar, por más que sea notorio, el papel central que han desempeñado en el nuevo modelo histórico-crítico los trabajos de José Escobar a partir de uno fundamental: «La mímesis costumbrista» (1988a); marbete este que ha terminado por sobrepasar sus aportaciones para entrar a formar parte -así lo registraba el propio Escobar diez años después de aquel artículo (1998: 18) - de la terminología de los estudios sobre la literatura española de los siglos XVIII y XIX ${ }^{2}$. La clave de la propuesta del profesor Escobar estriba en buscar el fundamento de la literatura costumbrista en la transformación del concepto de mímesis operada en el XVIII: en lugar de la imitación de la naturaleza como idea abstracta y universal de la estética racionalista del clasicismo, la nueva mímesis, local y temporalmente circunscrita, lo es del hombre en sociedad.

\footnotetext{
1 A ese monográfico le habían precedido dos encuentros científicos: vid. AA. VV. (1996) y Álvarez Barrientos y Romero Ferrer, eds. (1998).

2 Entre las fechas de ambos trabajos (1988-1998), han visto la luz otros (1992, 1993, 1994, 1996) en que Escobar reitera, desarrolla y perfila los ejes teóricos de su modelo.

Rlit, LXV, 129 (2003), 85-117
} 
Tal planteamiento entraba en claro conflicto con el modelo anterior, consagrado por la antología costumbrista de Correa Calderón $\left(1950,2 .^{\text {a }}\right.$ ed.: 1964), aunque ya fraguado en la segunda mitad del XIX a partir de motivaciones nacionalistas. El propio Escobar (2000) se ha ocupado de poner al descubierto esos presupuestos ideológicos de un modelo que, enraizando el costumbrismo en nuestro siglo XVII, se proponía presentarlo como forma de una supuesta identidad del realismo español. Opuesto por el vértice había sido el punto de partida de Escobar en 1988: caracterizó entonces el costumbrismo como fenómeno artístico de carácter transnacional, por lo que demandaba que se estudiase con la metodología propia de la literatura comparada y que se tuviese en cuenta su fundamentación teórica en el XVIII europeo.

Al presentar el cuadro de costumbres junto con la novela moderna y el drama burgués como génerós originados por el cambio del concepto de imitación en el XVIII, Escobar (1988a y 1992) enfoca su relación desde el horizonte de la intertextualidad; y, en consonancia con su punto de partida, defiende la legitimidad literaria del costumbrismo como fenómeno artístico propio de la modernidad. A fin de valorar el giro dado, recuérdese que el autor del tan citado Costumbrismo y novela - o «Ensayo sobre el redescubrimiento de la realidad española»— no había ocultado que el primero no le interesaba en sí mismo sino sólo en función de la segunda como avezamiento en la captación de tal tipo de realidad (vid. Montesinos, [1960] 1965: 8, 12 y 42).

Como la superación de los enfoques dominantes a mediados del $\mathrm{xx}$ - Correa (1950), Montesinos (1960) - se había ya planteado desde varios frentes, es obligada la referencia, por más que sea breve, a otros relevantes críticos $^{3}$. En primer lugar, a Russell P. Sebold por un memorable artículo de 1981, donde denunciaba esta tesis sobreentendida que se desprende de la obra de Montesinos: más que cultivadores de un género propio, los costumbristas fueron novelistas fracasados. Sebold ve también nexos del costumbrismo con la novela realista posterior, pero asimismo con la comedia de costumbres del siglo XVIII, géneros todos ellos que tienen contraída una deuda con la filosofía inductiva de Bacon y el sensualismo de Locke y Condillac, bajo cuya influencia sitúa el inicio del realismo moderno.

\footnotetext{
${ }^{3}$ Dejo aparte la tesis de Ferreras ([1970] 1973: 185-190), por cuanto, por subvertidora que parezca - no determina, positiva o negativamente, el costumbrismo a la novela, sino que es un subgénero de ella-, al entroncar al primero con el XVII, coincide en este punto con Correa, para quien el costumbrismo era «consecuencia de las formas novelísticas»: «La unidad narrativa se ha roto definitivamente, al menos en dos siglos, y cada uno de esos fragmentos [...] cobra su propia categoría» (Correa, [1950] 1964: p. XIVb); si bien, hay que añadir, para Correa era el costumbrismo germen de la novela realista del XIX, con lo que el proceso completo podía representarse, en su opinión, con una curva de parábola (vid. p. XLVIIb).
} 
Igualmente valioso es un trabajo de Leonardo Romero Tobar de 1983, de entre cuyas aportaciones me interesa destacar ésta: la valoración, en contraste con Montesinos, del discurso crítico de Mesonero, que, al insertar el artículo de costumbres entre la novela y el teatro, mostraba ser consciente tanto del común presupuesto estético - la imitación - como de las diferencias entre esos géneros fronterizos (1983: 251; vid. también 1994: 428-429) ${ }^{4}$. Y es con el registro del progresivo interés por la vertiente crítica de Mesonero - otra forma de revalorización del costumbrismo- con el que, si bien de forma apresurada, quiero cerrar este preámbulo ${ }^{5}$.

\section{LA OPCiÓN COSTUMBRISTA DE MESONERO, EN DIÁLOGO CON OTROS GÉ- NEROS FRONTERIZOS: LA OPOSICIÓN NOVELA/TEATRO}

Aunque somero, el repaso anterior me permite mostrar de forma explícita el contexto histórico-crítico en que se inserta este trabajo. En él abordo las relaciones del artículo de costumbres con otros géneros - la novela y el teatro-, tal como aquellas se delinean a lo largo del discurso crítico de Mesonero. Además, tendré en cuenta otros textos teóricos. Entre ellos, dado el alcance transnacional de la «mímesis costumbrista», algunos extranjeros, que, aunque conocidos, pueden todavía, en mi opinión, suministrarnos opimos frutos. Ojalá que de éstos no sea el menor el contribuir al ensanchamiento de unos horizontes tantas veces circunscritos a la incidencia de nuestro costumbrismo en la posterior novela realista española ${ }^{6}$.

Mi indagación sobre el discurso crítico de Mesonero - que no sobre su praxis costumbrista o sus repercusiones- se abrirá a la complejidad de perspectivas que admiten los géneros literarios. Unas veces, determinadas por el cambio: «Géneros y diacronía están» - como bien se ha dicho (Garrido, 1988: 22)— «inextricablemente relacionados». Otras, por el juego que

\footnotetext{
${ }^{4}$ Por reveladores de la inversión operada, compárense estos juicios sobre Mesonero: «sus ideas de la novela (lo acreditan muchos pasajes de sus artículos) no eran del todo claras; y aun esos mismos pasajes atestiguan que la novela no le interesaba cosa mayor» (Montesinos, [1960] 1965: 16); «tenía ideas muy claras acerca de la función social y las técnicas de construcción de los relatos» (Romero, 1983: 254).

${ }^{5}$ Los estudios de las ideas literarias de Mesonero muestran una vez más la pluralidad de líneas en la investigación sobre nuestro costumbrismo: su dependencia de modelos europeos (Escobar, 1977a y b), su incidencia en realistas posteriores como Galdós (Miller, 1980 y 1983), sus nexos con el XVIII (Álvarez Barrientos, 1994 y 1995) o la herencia clasicista (Comellas, 1996). Como nueva prueba del interés por los planteamientos de don Ramón, aduzco la edición de Pilar Palomo (1987), muy útil por los textos de sus apéndices II y III.

${ }^{6}$ Dada la abundancia de títulos, remito al panorama crítico de Romero Tobar (1994: 426-430; también 397 y ss.), a las revisiones bibliográficas de Rubio Cremades (1995: 18 y ss.; 1997: 153-154) y al estudio de Palomo (1989) sobre la relación entre Mesonero y Galdós.
} 
se establece en el cuadro de géneros de una época, ya que los propios de ella no constituyen configuraciones aisladas; antes bien, «un género pertenece a una estructura de géneros, a un sistema de opciones literarias» (Guillén, [1971] 1989: 240). Ambas perspectivas no deben entenderse como la consagración de una dicotomía tajante entre sincronía y diacronía, negadora del carácter pluralista del proceso histórico, de la coexistencia de transformaciones y de continuidades propia de los sistemas literarios, de la que dan buen ejemplo los géneros (véase Guillén, [1977] 1989: 258-261).

Precisamente, si considero muy fértil el discurso crítico de Mesonero, es por plantear su elección genérica - los artículos de costumbres- en relación o diálogo con aquellos otros géneros en que el concepto de imitación experimentó una transformación en el XVIII; cambio que establecía nuevas interrelaciones y que, en consecuencia, obliga a registrar las novedosas concepciones fundadoras del nuevo sistema de géneros. Pero a la vez habrá que tomar en cuenta, para una completa comprensión, pervivencias heredadas de la más arraigada tradición teórica. Bien nos mostrará el pensamiento de Mesonero este entrecruzamiento de innovación y ecos de la tradición.

Una vez sentadas las bases de partida, no se puede sino juzgar como parcial un enfoque como el de Montesinos, interesado en subrayar la incapacidad de Mesonero para llenar el vacío de la novela moderna entre nosotros ([1960] 1965: 13-16) ${ }^{7}$. Es cierto que El Curioso Parlante presentó su propia producción costumbrista - remito al prólogo de su Panorama matritense de 1835, así como a la introducción de sus Escenas matritenses de 1842 - haciendo referencia previa a la novela y el teatro, los géneros hacia los que más se inclinaba su afición, según reconoció en su discurso de ingreso en la RAE en 1838 (1883: 32 y 41). Y es verdad que, en esa introducción de 1842, se justificó como sigue: dadas las condiciones literarias y extraliterarias para el cultivo de ambos géneros en la España de su tiempo, la pintura de los usos y costumbres populares se había tenido que refugiar en los artículos sueltos de costumbres (1987: 352-353).

Todo esto, sin embargo, no debe oscurecer el muy significativo hecho de que los géneros relacionados por Mesonero son los tres afectados por el cambio del XVIII; ni tampoco debe impedirnos caer en la cuenta de que el escritor no sólo se apoyó en la novela y el teatro para definir sus artículos - como tantas veces se ha recordado ${ }^{8}$-, sino que paralelamente

\footnotetext{
${ }^{7}$ Lo sorprendente es que, no obstante, Montesinos parezca deudor de la visión sobre la novela española de la época abocetada por Mesonero y otros a mediados del XIX: sin duda, favoreció su difusión el eco que obtuvo luego en autores como el Galdós de las Observaciones sobre la novela contemporánea en España de 1870 (vid. Ferraz, 1992: I, 1-28).

${ }^{8}$ Una vez más: «propúseme desarrollar mi plan por medio de ligeros bosquejos o cuadros de caballete en que, ayudado de una acción dramática y sencilla, caracteres ve-
} 
recurrió, para caracterizar la novela de costumbres, a notas que podrían aplicarse por igual a esos artículos ${ }^{9}$. Este tipo de interrelaciones no debe considerarse privativo de Mesonero. Pueden alegarse otros textos de coetáneos suyos que muestran una clara conciencia de la comunión entre géneros distintos en virtud de su idéntica orientación mimética. Por ejemplo, al reseñar en 1836 el Panorama matritense de Mesonero, Larra (1960: II, 240b) puso a la cabeza de los escritores de costumbres a un novelista como Balzac. Y en sentido inverso, Ucelay da Cal (1951: 168 y 170) señaló que tanto Fernán Caballero como Antonio Flores relacionaron su producción novelesca con Los españoles pintados por sí mismos (1843-1844).

Pueden aducirse, asimismo, ciertas metáforas tópicas —el retrato, la pintura, el espejo o, más moderna, el daguerrotipo (Ferraz, 1996 y 1998) por ser comunes a textos diversos de orientación mimética. La del espejo, aplicada tradicionalmente a la comedia -ésta se veía, de acuerdo con una opinión (supuesta) de Cicerón, como imitación de la vida, espejo de las costumbres e imagen de la verdad (Abrams, [1953] 1975: 63) - la hizo extensible Mesonero a otros géneros miméticos: en 1833 se refería a su producción costumbrista como «espejo fiel en que mirar nuestras inclinaciones, nuestros placeres y también nuestras virtudes, nuestros defectos y ridiculeces» (1967: I, 189a); y luego en su discurso de ingreso en la RAE definirá a la novela y el teatro como espejos de la vida social (1883: 31). También Larra acudió a la imagen del espejo para caracterizar tanto la comedia (1960: I, 383a) como el Panorama matritense de Mesonero (Larra, 1960: II, 243b).

Más que la pervivencia de tópicos tradicionales, me importa ahora destacar el eco del nuevo concepto de mímesis en costumbristas, novelistas y dramaturgos. Pues la aspiración a reflejar la realidad de la sociedad presente y circundante es lugar común en declaraciones de autores del XVIII y el XIX: limitándome a los españoles, valgan los casos de don Ramón de la Cruz (1786), Estanislao de Cosca Vayo (1827), Mesonero (1832) o de Tomás Rodríguez Rubí $(1847)^{10}$. Establecida esta identidad de propósitos,

rosímiles y variados y diálogo animado y castizo, procurase reunir, en lo posible, el interés y las condiciones principales de la novela y del drama» (Memorias de Mesonero, 1967: V, 188a, y 1994: 430; vid. también 1881: p. VII).

${ }^{9}$ Compárese esta definición con la de la nota anterior: «un cuadro verdadero, una acción fácil y verosímil, personajes semejantes a los que existen en toda sociedad, escenas y diálogos llenos de animación y movimiento» (Mesonero, 1839: 254 a, y 1883: 35).

${ }^{10} \mathrm{Cfr}$. estas propuestas: «copiar lo que se ve, esto es, retratar los hombres, sus palabras, sus acciones y costumbres» (Cruz, 1786, apud Álvarez Barrientos, 1990: 228); «contar los sucesos sencillamente, sacándolos del ejemplo y de los objetos que me han rodeado» (Vayo, 1827: I, p. XII); «consultar en mis discursos la impresión que en mí producen los objetos que me rodean» (Mesonero, 1832, apud Escobar, 1977b: 19); «qué ha de hacer el teatro al desempeñar su papel de retratista sino usar los colores que la sociedad misma le sirve de paleta» (Rodríguez Rubí, 1847, apud Romero Ferrer, 1998: 134). 
se hace obligado preguntarse por cuáles eran las diferencias entre los géneros miméticos a los ojos de Mesonero. Nada mejor para ello que fijarse en los valores distintivos - se trata de pinceladas o matices que, en una lectura rápida, pueden pasar inadvertidas - con que acompaña sus definiciones de esos genéros. Para empezar, volvamos a la metáfora del espejo y reparemos en cómo la califica Mesonero al aplicarla al teatro: «el observador de las costumbres acudirá siempre a buscar en el teatro el espejo más fiel de la sociedad que desea conocer», dice en 1835 (1987: 346). Este aprecio del espectáculo teatral por su intensidad (re)presentativa permanecerá vivo en Mesonero muchos años después, como atestiguan sus Memorias de un setentón, donde leemos que el teatro «seguramente es el medio más eficaz para reflejar las costumbres sociales» (1967: V, 187b, y 1994: 429) ${ }^{11}$. No se crea por ello que Mesonero minusvaloraba el poder mimético de la novela, a la que dedicó la mayor parte de su discurso de ingreso en la RAE en 1838. Entonces dijo de ella que era «el reflejo inmediato de toda sociedad» (1883: 39; también 1839: 254b). Esta función era para él el rasgo más definitorio de la novela, pues, si bien admitía distintas variedades -fantástica o maravillosa, de costumbres e histórica-, es con la de costumbres con la que, en su opinión, el género se centra en «su verdadera condición de retratar a la sociedad tal cual es» (1883: 35-36; también 1839: 254a).

Mas esta reducción de todo el género novelesco a una de sus variedades, tan reveladora de las preferencias de Mesonero, no podía presentarla sin más como etapa final culminante, tal como, en cambio, podría deducirse del influyente manual de Hugo Blair -Lecciones sobre la Retórica y las Bellas Letras (1. ${ }^{a}$ ed. española de 1798-1801)—, donde se traza su historia como un proceso que va de lo maravilloso a la imitación de la vida y caracteres de los hombres (1800: III, 291-306) ${ }^{12}$. Con la difusión de la novela histórica de Walter Scott, Mesonero estaba ya obligado a convertir la dualidad de la novela fantástica o maravillosa y de costumbres en un conjunto ternario.

A fin de valorar la postura que Mesonero, defensor de la novela como reflejo de la sociedad, toma ante ese nuevo cuadro genérico, nos valdrá el contraste con Alberto Lista. Aunque éste apreciaba a Walter Scott, era sobre

${ }^{11} \mathrm{La}$ referida intensidad (re)presentativa —atributo en que compendio los de fidelidad y eficacia señalados por Mesonero- apunta a lo que García Barrientos (2001: 42 y 196-198) juzga como rasgo distintivo del modo de imitación dramático frente al narrativo: el carácter inmediato de su (re)presentación, que le confiere la máxima ilusión de realidad.

${ }_{12}$ No obstante ese término, el tratado de Blair fue el principal foco difusor de una tesis de Bacon - la apetencia humana de historias ficticias- que favoreció la asociación de la novela con la poesía y la imaginación, lo extraordinario y lo ideal (vid. Ferraz, 2000). 
todo por su descripción de las costumbres pretéritas; y, además, reservaba para un futuro próximo el triunfo de la novela satírica y de costumbres (1844: I, 156). Mesonero, por su parte, apostaba en 1838 por la combinación de ambas clases, la de costumbres contemporáneas y la histórica, lo que ha llevado a considerarlo precedente de propuestas muy posteriores de Galdós (Miller, 1980: 10, y 1983: 65-66; Romero Tobar, 1983: 252), si bien pueden citarse otras más próximas a él en esa línea (Ferraz, 1992: I, 331 y 564 y ss. ${ }^{13}$.

Para apreciar la propuesta de Mesonero, no es forzoso acudir a ilustres vínculos. Tales nexos son posibles porque aparecen imbricadas importantes notas de la novela moderna: su hibridismo y su ambición de totalidad como pintura de una sociedad y de una época; cuadro que es posible formar gracias a la fusión de géneros. Entonces la novela, decía en 1838, «reúne las más ventajosas condiciones del teatro, de la cátedra y de la historia» (1883: 38, y 1839: 254b). En '1842 volverá a insistir en la capacidad de mímesis social de la novela moderna: «género el más apropiado para pintar holgadamente los caracteres, la acción y el idioma vital de la sociedad; género que ha penetrado en el recinto de la historia, ha sustituido a la poesía épica; ha luchado ventajosamente con el drama; y ha llegado a hacer populares hasta los recónditos misterios de las artes, avasallando de este modo la imaginación, y todos los medios de que se puede valer la filosofía para pintar el corazón humano» (1987: 352). He subrayado un término por cifrar en él Mesonero la principal ventaja de la novela frente al teatro, pues éste, a pesar de su eficacia, «era insuficiente - así lo reconoció en sus Memorias - para recorrer, como yo deseaba, todas las clases» (1967: V, 187b, y 1994: 429; el subrayado es mío).

La novela, en definitiva, era para Mesonero el medio más completo para la pintura de la sociedad, sobre todo si, como género híbrido, era capaz de sumar las virtudes de otros (de nuevo puede constatarse, y no sólo a propósito de los artículos de costumbres, que Mesonero no ve irreductiblemente aislados los géneros, que comprende la literatura moderna como juego de relaciones). Ahora bien, al oponer novela y teatro - extensión frente intensidad (re)presentativa-, era heredero asimismo de un sistema consagrado por la tradición teórica.

Múltiples testimonios prueban que era tópica la oposición entre dos formas de imitación: la acción teatral dialogada, que goza de mayor ilusión por su carácter (re)presentativo, y la extensa narración novelesca, capaz de desarrollar una amplia variedad de episodios. Para no extenderme, citaré sólo dos textos próximos en el tiempo a los aducidos de Mesonero. El primero, de 1841, es de Nicomedes Pastor Díaz: «El teatro mismo no

${ }^{13}$ Vid. Álvarez Barrientos (1995: 31) sobre precedentes dieciochescos de la idea de Mesonero y Galdós de la sociedad como materia novelable. 
es más que la novela en acción; la novela es un teatro más extenso todavía, de más interés acaso, aunque de menos ilusión de realidad» (1969: I, 119b). Siete años después, Eugenio de Ochoa escribía: «el drama, si bien se mira, no es más que una especie de pequeña novela dialogada; o lo que es lo mismo, la novela, en cierto modo, no es más que un drama narrado, desleído en uno o más volúmenes, y enriquecido por consiguiente con todos los pormenores y todo el desarrollo, digámoslo así, de que, por su poca extensión y por su misma naturaleza, no es éste susceptible» (1848: 272).

A los textos recién mencionados podrían añadirse otros similares de la misma época ${ }^{14}$; y asimismo de precedentes ${ }^{15}$. Tal cantidad de voces no hace sino apuntar a un fundamento teórico clásico: la Poética de Aristóteles (1448a19-24; 1449b11-14; 1455b15-16; 1459b17-30). Allí se diferencia entre dos modos de imitación, bien narrando, bien «presentando a todos los imitados como operantes y actuantes»; y se caracteriza la epopeya, en contraste con la tragedia, por ser un relato, por su extensión ilimitada en el tiempo y la amplitud de sus episodios, por poder presentar muchas partes de la acción realizándose simultáneamente (ed. García Yebra, 1974: 132$133,142-144,190,218-220)$. Estas ideas inspirarán una legión de poéticas posteriores. Así, Luzán dirá que en el poema épico es posible la variedad de episodios por «ser la epopeya una narración y, consiguientemente, no sujeta a tiempo tan limitado ni a otros miramientos que debe tener la representación dramática» (ed. 1977: 578).

Semejante caracterización de la epopeya la hizo suya, acabamos de verlo, la novela, género sin el prestigio de otros considerados más nobles $\mathrm{y}$, por tanto, merecedores de la reflexión teórica. Y a partir de la nueva oposición novela/teatro, se pudo realzar la mayor libertad y riqueza en

\footnotetext{
${ }^{14}$ Larra no juzgaba fácil formar un drama a partir de una novela por el riesgo que tienen de caer en un embrollado y mal deslindado argumento «los dramáticos que pretenden hacinar y estrechar en los cortos límites de un cuadro representable en horas los sucesos y caracteres diseminados y desleídos en la dilatada extensión de una larga novela» (1960: I, 232a). Y sobre El Trovador de García Gutiérrez dirá: «Ha imaginado un plan vasto, un plan más bien de novela que de drama, y ha inventado una magnífica novela; pero al reducir a los límites estrechos del teatro una concepción demasiado amplia, ha tenido que luchar con la pequeñez del molde» (1960: II, 169a).

${ }^{15}$ En Los literatos en Cuaresma (1773) de Tomás de Iriarte se defiende así la distinción entre ambos géneros: la comedia «representa los sucesos puestos en acción; y la novela los ofrece en relación»; por eso la segunda puede «comprender los acontecimientos de toda la vida de un hombre», lo que no es verosímil en el teatro (apud Álvarez Barrientos, 1991a: 105-106). Ese contraste también aparece en quienes, como Vicente María de Santiváñez en 1787, admitían la posibilidad de trasvases: «Quítese a la Comedia el aparato teatral: introdúzcase un escritor que haciendo las veces de un espectador ilustrado, una entre sí los dichos de los personajes, mezclando oportunamente, y quedará una Novela. Por el contrario, quítese a ésta la narración, redúzcase a diálogo, y resultará una comedia» (apud Checa, 1998: 263).
} 
pormenores, episodios o desarrollo de la primera ${ }^{16}$. La ponderación de esa libertad y amplitud podía derivar en una valoración de la capacidad de la novela para la mímesis de las costumbres de la sociedad entera. Por eso admiraba Larra a Balzac. Después de leerlo - dirá precisamente con ocasión de la reseña del Panorama matritense de Mesonero- «puede decir el lector que conoce la Francia y su sociedad moderna», pues «Balzac ha recorrido el mundo social» (1960: II, 240b). Y, por eso mismo, Mesonero veía en la novela el género más apropiado para pintar holgadamente la sociedad y, en cambio, lamentaba que el teatro, pese a su eficacia mimética, no le diese oportunidad de hacer un recorrido por todas las clases.

\section{INTERMEDIO EUROPEO: LA NOVELA COMO DRAMA EXTENSO (DIDEROT) Y LAS COLECCIONES COSTUMBRISTAS FRANCESAS COMO PANORAMAS}

De distinciones heredadas de las poéticas clásicas se derivó, como hemos visto, una apoyatura teórica para caracterizar el género novelesco; sin embargo, no podía resultar suficiente para explicar la novela moderna en cuanto integrante del nuevo sistema genérico inaugurado por el transformador concepto de imitación que trajo el XVIII. No quiere esto decir que se deba desdeñar el juego de contrastes entre novela y teatro forjado a partir de la oposición clásica entre epopeya y tragedia; sino que hay que situarlo ahora en un marco de relaciones en el que la novela compartía con el teatro una nueva concepción mimética. Y al enfocarlas así, aquellas distinciones cobrarán nuevo valor.

De hecho, la reflexión teórica sobre el teatro había sido el punto de arranque para el nuevo concepto de imitación del XVIII, trasladado luego al campo de la novela. Es el trasvase que lleva a cabo Diderot desde sus Entretiens sur le Fils Naturel (1757) al Eloge de Richarson (1762), de suerte que la apología que en esta última obra se hace de la novela - ya lo advirtió Hans Robert Jauss (1969: 157-158) - no se apoya en la epopeya, como habían hecho otros, pues las novelas de Richardson no consistían en ficciones irreales y romancescas; antes bien, en auténticas copias del mundo que le rodeaba. El punto de referencia es ahora la verosimilitud realista del drama moderno ${ }^{17}$.

16 Ahí residía para Guillermo Forteza la diferencia de la novela: «no ceñida a determinadas proporciones, los episodios artísticamente incrustados en su trama imaginativa realzan y suben de punto la acción principal, cosa de muy difícil logro en el drama» (1857: 5). Fernández Espino añadía a continuación: «su dominio es más extenso y libre que el del Drama» (1857: 7). Algo antes, Eugenio de Ochoa había destacado la mayor riqueza de la novela en pormenores y desarrollo (1848: 272).

${ }_{17}$ Se trata de una dirección - del teatro a la novela - inversa a la de la teoría decimonónica estudiada por Russel P. Sebold según la cual «la técnica romántica se forma 
En su elogioso comentario de las novelas de Richardson como imitaciones de la realidad de la vida, Diderot concedió especial protagonismo a los pequeños detalles en cuanto medios para lograr la ilusión de verdad. Se trata del cambio de orientación hacia lo particular y circunstancial, en lugar de la imitación de una naturaleza abstracta, sobre el que ha venido llamando la atención entre nosotros - recuérdese- el profesor Escobar. Por mi parte, me propongo poner en relación con esta nota otra, que no la contradice, sino que más bien la desarrolla: la ambición de abarcar de forma plena y completa las realidades humanas. Porque, por más que se atuviese a las circunstancias particulares, eso no significaba renuncia - antes bien, lo contrario - a una visión plena de la vida. Con esa visión se asoció en el XVIII la novela moderna, pues, dada su capacidad, el género aparecía muy apto para una mímesis realista y abarcadora.

Creo oportuno recordar que la complementariedad de ambas notas - una mímesis de lo particular, con ambición a la vez de plenitud- coincide con lo que es para el autor del tan citado The Rise in the Novel la premisa o convención primaria de la moderna novela realista inglesa que surge en el XVIII: a saber, que la novela es una relación completa y auténtica de la experiencia humana y que, por ello, está obligada a proporcionar a los lectores cuantos detalles de la historia exijan la individualidad de los actores y las particularidades de los tiempos y lugares de sus acciones, a través de un lenguaje mucho más referencial que el de otras formas literarias, a las que supera por su imitación más inmediata (Watt, [1957] 1977: $35)^{18}$. Esta aspiración de la novela a la inmediatez a la vez que a la plenitud de la representación perdurará a lo largo del XIX y XX, siglos en que se escucharán declaraciones de escritores en esa dirección ${ }^{19}$.

Ahora es al XVIII, sin embargo, al que invito a dirigir la mirada. Más en concreto, a las páginas del ya mencionado Eloge de Richardson (1762), pues ya se exponen allí de forma explícita los principios que guían la novela moderna. Aclaro que no es mi propósito pasar revista a todas las ideas que

por las repetidas incursiones de lo novelístico en otros géneros literarios, señaladamente el teatro»; teoría que ponía en relación «romanticismo» con otras voces de la familia de «romance», o «relato extenso en prosa de sucesos fuera de lo común» (Sebold, [1979] 1983: 138 y 143). El contraste entre ambas líneas resalta más si anticipo que Diderot defiende las novelas de Richardson de la censura de ser extensas y ocuparse de la vida común.

${ }^{18}$ Ian Watt ([1957] 1977: 23) recoge este juicio de Spengler que va en la misma dirección: la expansión de la novela responde a la necesidad que siente el hombre moderno ultrahistórico de una forma literaria capaz de tratar la totalidad de la vida.

19 A la voz de Mesonero - la novela es «el reflejo inmediato de toda sociedad»pueden sumarse otras como la de Clarín, que en 1881 y 1885 juzgó la novela como el género más adecuado para reflejar la realidad y la vida toda sin caer en abstracciones (Lissorgues, 1998: 13-14). Para el Xx, valga la definición de D. H. Lawrence de la novela como representación plena de la vida (Sauvage [1965] 1982: 99-101). 
Diderot desarrolla en esta obra, ni siquiera demorarme en la tan subrayada de que las novelas del inglés mostraban al lector, produciéndole una profunda ilusión, el mundo circundante ${ }^{20}$. Sobre lo que quiero llamar la atención es sobre esta otra idea que precede a la anterior en el discurso de Diderot: las novelas de Richardson llevan al lector a recorrer en el intervalo de unas horas un gran número de situaciones, que una vida, por más dilatada que pueda ser, apenas le ofrece en toda su extensión ${ }^{21}$.

Después de ponderar su capacidad para captar una gran variedad de sucesos, relaciones, personajes y matices, Diderot calificó la novela al estilo de Richardson de más verdadera que la propia Historia ${ }^{22}$. Mayor trascendencia tiene la asociación que Diderot establece con otro género: el drama que había hecho objeto de su mímesis la sociedad burguesa de su tiempo. Pues Diderot se admiraba de la prodigiosa capacidad mental que era precisa para conducir esos «dramas de treinta a cuarenta personajes» en que consistían las ricas novelas de Richardson ${ }^{23}$. Si las definía así, era porque veía aunados los valores del drama moderno —es decir, el nuevo principio realista de imitación- y la amplitud de campo de que era capaz la novela.

Esta convergencia fue lo que censuraban algunos coetáneos. Les desagradaban las novelas de Richardson por su prolijidad y extensión, por su exceso de detalles, por detenerse en pintar lo común, lo que se ve todos los días. A esas críticas Diderot respondió oponiendo estas razones: una, la intensidad y penetración de la mirada de Richardson, cuyo arte, como el de los grandes poetas y pintores, tiene la facultad de mostrar las circunstancias fugitivas que a los demás se les escapan; la otra, la ilusión

20 «Le monde où nous vivons est le lieu de la scène; le fond de son drame est vrai; ses personnages ont toute la réalité possible; ses caractères sont pris du milieu de la société; ses incidents sont dans les moeurs de toutes les nations policées; les passions qu'il peint sont telles que je les éprouve en moi; [...] il me montre le cours général des choses qui m'environnent. Sans cet art, mon âme se pliant avec peine à des biais chimériques, l'illusion ne serait que momentanée et l'impression faible et passagère» (Diderot, [1762] 1959: 30-31). La anterior nota 10 recoge textos de autores españoles del XVIII y XIX que hicieron suyo un enfoque similar.

21 «J'avais parcouru dans l'intervalle de quelques heures un grand nombre de situations, que la vie la plus longue offre à peine dans toute sa durée» (Diderot, [1762] 1959: 30).

22 «O Richardson! j'oserai dire que l'histoire la plus vraie est pleine de mensonges, et que ton roman est plein de vérités. [...] Sous ce point de vue, j'oserai dire que souvent l'histoire est un mauvais roman; et que le roman, comme tu l'as fait, est une bonne histoire» (Diderot, [1762] 1959: 39-40).

23 «Je ne me lasserai point d'admirer la prodigieuse étendue de tête qu'il t'a fallu, pour conduire des drames de trente à quarante personnages, qui tous conservent si rigoureusement les caractères que tu leur as donnés: l'étonnante connaissance des lois, des coutumes, des usages, des moeurs, du coeur humain, de la vie; l'inépuisable fonds de morale, d'expériences, d'observations qu'ils te supposent» (Diderot, [1762] 1959: 40). 
que se desprende de eșa multitud de pequeñas $\operatorname{cosas}^{24}$. Añádase que, al comentar los efectos de la lectura de las novelas de Richardson, Diderot ponderó la sensación de persistencia continua en la realidad circundante que experimentaba el lector u observador de tan extenso cuadro ${ }^{25}$.

Es cierto que igualmente el teatro aspiró en el XVIII a ser representación de la vida burguesa en todas sus situaciones y, por ello, más auténtica que la Historia con mayúsculas, pues ésta desatendía la vida ordinaria ${ }^{26}$. Pero también lo es que el teatro conllevaba restricciones en comparación con la amplitud de la novela, según el tópico que venimos comentando ${ }^{27}$. No quedarse en la mera contraposición entre ambos, antes bien, ver los puntos de confluencia de la novela y el drama modernos, sin por ello desconocer sus diferencias, constituye el original enfoque de Diderot, plasmado en la expresión «dramas de treinta a cuarenta personajes» que aplica a las novelas de Richardson. Al adoptar éstas la verosimilitud realista del drama, era como si éste ensanchase su campo.

No está de más recordar que Diderot pensaba en la ampliación de los límites convencionales del teatro de su tiempo. La defiende en Entretiens sur le Fils Naturel Dorval con su propuesta de un mayor espacio para así superar la estrechez que impedía mostrar nada más que una acción, cuando en la naturaleza son casi siempre simultáneas: sus representaciones concomitantes producirían en los espectadores, al reforzarse recíprocamente, efectos terribles ${ }^{28}$. Con tal propuesta - prueba de que también podía

${ }^{24}$ «Ils sont communs, dites-vous; c'est ce qu'on voit tous les jours! Vous vous trompez: c'est ce qui se passe tous les jours sous vos yeux, et que vous ne voyez jamais. Prenez-y garde; vous faites le procès aux plus grands poétes, sous le nom de Richardson. [...] et l'art du grand poète et du grand peintre est de vous montrer une circonstance fugitive qui vous avait échappé.[...] Sachez que c'est à cette multitude de petites choses que tient l'illusion: il y a bien de la difficulté à les imaginer; il y a en bien encore à les rendre» (Diderot, [1762] 1958: 35).

${ }^{25}$ «Un des avantages de son travail, c'est qu'ayant embrassé un champ immense, il subsiste sans cesse sous mes yeux quelque portion de son tableau» (Diderot, [1762] 1959: 38).

${ }^{26}$ Mercier dirá en 1773: «Le Drame (on ne sauroit trop le répeter) est la représentation, le tableau de la vie bourgeoise en toutes ses situations» (apud Escobar, 1988a: 265). Y en 1786 don Ramón de la Cruz definirá sus sainetes como «pintura exacta de la vida civil y de las costumbres españolas», por lo que nadie podía negar que representasen —decía- «la historia de nuestro siglo» (apud Álvarez, 1990: 228).

${ }^{27}$ Este tópico seguirá vigente en el XIX y XX: en «El naturalismo en el teatro», Zola opondrá a los convecionalismos de la escena el cuadro sin límites de la novela (Lissorgues, 1998: 13); y en The Rethoric of Fiction, W.C. Booth destacará la mayor capacidad de la novela para la representar la compleja experiencia humana: una obra teatral de dos horas tiene que apoyarse en dicotomías en cierto modo simples y no puede mostrar tantas matizaciones (Sauvage, [1965] 1982: 101, n. 123).

${ }^{28}$ «Je ne demanderais, pour changer la face du genre dramatique, qu'un théâtre très étendu, où l'on montrât $[. .$.$] différents endroits distribués de manière que le spectateur$ vît toute l'action, et qu'il y en eût une partie de cachée pour les acteurs.[...] Exécuterons- 
aspirarse a una imitación más abarcadora en el marco de la representación dramática ${ }^{29}$, no se cuestionaba sino un tipo de teatro y no quedaban anuladas las diferencias genéricas. Así, en la primera de las entrevistas mencionadas, cuando se aborda la cuestión de las unidades, encontramos una contraposición que nos es familiar: una multitud de incidentes proporcionaría verdad a una novela, pero quitaría todo interés a una obra dramática ${ }^{30}$; oposición que tiene luego su paralelo en esta otra: en contraste con la escena, la epopeya abraza multitud de sucesos diferentes y situaciones ${ }^{31}$.

En conclusión, en el discurso de Diderot sobre la novela, confluían la extensión - rasgo tradicionalmente asociado a la epopeya- y la ilusión de realidad del drama moderno. De muy ambiciosa puede calificarse la imitación que se proponía esa nueva novela: tanto por la amplitud del campo, con la consiguiente sensación de persistencia continua, como por la penetración o intensidad de la mirada del novelista, capaz de revelar aspectos siginificativos de la realidad.

No fueron ajenas a estos planteamientos las reflexiones de los escritores de costumbres. Su eco resuena ya en el inaugurador del género de cuadros de París, Louis-Sébastien Mercier, que traslada el concepto de imitación del drama del XVIII a la literatura de costumbres. La tendencia que le había llevado a Diderot a ensanchar y abrir el drama a la macroestructura de la novela es la misma - señala Stierle (1980: 347) - que mueve a Mercier a concebir el «tableau» como forma de representación de la gran ciudad con la inmensidad de sus fortunas y constelaciones morales. En las páginas iniciales de su Tableau de Paris (1781), L-S. Mercier hace suyos

nous rien de pareil sur nos théâtres? On n'y peut jamais montrer qu'une action, tandis que dans la nature il y en a presque toujours de simultanées, dont les représentations concomitantes, se fortifiant réciproquement, produiraient sur nous des effets terribles» (Diderot, [1757] 1959: 114-115).

${ }^{29}$ Antes me he referido a la caracterización que, en contraste con la tragedia, hace Aristóteles de la epopeya, entre cuyas notas sitúa la de poder «presentar muchas partes realizándose simultáneamente». Idea que completo con la que le antecede en su exposición: «en la tragedia no es posible imitar varias partes de la acción como desarrollándose al mismo tiempo, sino tan sólo la parte que los actores representan en la escena» (Poética, 1459b22-26; ed. García Yebra, 1974: 218-219).

30 «Dans la société, les affaires ne durent que par de petits incidents, qui donneraient de la vérité à un roman, mais qui ôteraient tout l'intérêt à un ouvrage dramatique: notre attention s'y partage sur une infinité d'objets différents; mais au théâtre, où l'on ne représente que des instants particuliers de la vie réelle, il faut que nous soyons tout entiers à la mème chose « (Diderot, [1757] 1959: 81).

31 «Rappelez-vous - dice Dorval- qu'il ne s'agit, sur la scène, que d'une seule action, que d'une circonstance de la vie, que d'un intervalle très court, pendant lequel il est vraisemblable qu'un homme a conservé son caractère». Y su interlocutor le pregunta: «Et dans l'épopée, qui embrasse une grande partie de la vie, une multitude prodigieuse d'événements différents, des situations de toute espèce, comment faudra-t-il peindre les hommes?» (Diderot, [1757] 1959: 160). 
los postulados del vasto cuadro - todas las clases de la gigantesca capital, todo un mundo cuyas dimensiones eximen de explorar otros lugares ${ }^{32}-\mathrm{y}$ de la visión penetrante del escritor que sabe observar realidades que los habitantes de París, a fuerza de verlas, ya no perciben, por lo que se comportan como extranjeros en su propia ciudad ${ }^{33}$.

Estos tópicos subsisten en otras obras que siguen por la senda de Mercier. Incluso sirven para justificar el cambio que introduce Paris, ou le Livre des Cent-et-un (1831-1835) como texto de autoría múltiple. Porque, si se trata de una «peinture multiple», es por su ambición de totalidad: «ce drame à cent actes divers» la bautizó el Journal des Débats (1831: I, pp. VII y IX). Y aunque se hace referencia al símbolo tradicional de la observación, el diablo Asmodeo - la obra se había anunciado con el título de Le Diable Boiteux à Paris-, del que se nos recuerda que no está en ninguna parte $\mathrm{y}$, a la vez, en todas, es ahora el «flâneur» quien, en el contexto del dilatado campo de la moderna sociedad, encarna mejor la penetrante mirada descubridora de puntos de vista inesperados en la cambiante realidad circundante — «le panorama mobile»(1832: VI, 102)—, inadvertidos por los demás.

Posteriormente, en Les français peints par eux-mêmes (1840-1842), donde se promete al lector que nada faltará en tal obra colectiva - «une comédie en cent actes divers» ([s.a.]: I, 4a)—, se definirá al «flâneur» como un habitante de la vasta ciudad de París, teatro de sus constantes exploraciones, que sabe cosechar increíbles riquezas en ese gran campo de observación, en cuya superficie se queda el hombre vulgar, mientras que él descubre bajo ella todo un mundo nuevo; y se verá en la «flânerie» el carácter distintivo del verdadero hombre de letras - «littérateurs parce que flâneurs» (II, 115a)—, que ilustran los casos, entre otros, de los costumbristas Mercier y Jouy.

La extensión del campo social abarcado y la intensidad de la mirada literaria eran, por tanto, ejes comunes a la ambiciosa mímesis de novelistas y costumbristas. En el caso de las extensas novelas de Richardson,

\footnotetext{
${ }^{32}$ Dice en el «Préface»: «J'ai fait des recherches dans toutes les classes de Citoyens, \& n'ai pas dédaigné les objets les plus éloignés de l'orgueilleuse opulence, afin de mieux établir par ces oppositions la physionomie morale de cette gigantesque capitale» (Mercier, 1781: I, p. V); y en «Tableau de Paris. Coup-d'oeil général»: «Un homme qui sait réflechir à Paris, n'a pas besoin de sortir de l'enceinte de ses murs, pour connoître les hommes des autres climats. Il peut parvenir à la connoissance entière du genre humain, en étudiant les individus qui fourmillent dans cette immense capitale" (Mercier, 1781: $\mathrm{I}, 1)$.

33 «Beaucoup de ses habitants font comme étrangers dans leur propre ville: ce livre leur apprendra peut-être quelque chose ou du moins, leur remettra sous un point de vue plus net \& plus précis, des scenes, qu'à la force de les voir, ils n'appercevoient pour ainsi dire plus; car les objets que nous voyons tous les jours, ne sont pas ceux que nous connoissons le mieux» (Mercier, 1781: I, pp. V-VI).
} 
Diderot había resaltado la sensación de persistencia continua de que gozaba el lector tras entregarse a su lectura. También aspiraban a una visión muy vasta las colecciones costumbristas, calificadas por Walter Benjamin (1972: 177), que las relacionó con los espectáculos coetáneos de los panoramas, como «literatura panorámica» (vid. también Baker, 1990: 206-208, y 1991: 64-67). Sin embargo, tales agrupaciones no dejaban de ser ramilletes discontinuos de textos diversos. Y esto no solo en el caso de colecciones integradas por escritos de muy distintos autores, sino también cuando se trataba de series de artículos debidos a una misma pluma.

De ahí que los propios autores destacasen ya en presentaciones y títulos elementos unificadores, tales como la materia tratada o la conciencia literaria que registraba y describía, como hace Mesonero en el subtítulo del Panorama matritense: "Cuadros de costumbres de la capital, observados y descritos por el Curioso Parlante» ${ }^{34}$. Antes que él, Mercier había ponderado los «cuadros» y la «galería de imágenes» de Paris que impresionaban y hablaban a quien sabía ver y prestar oídos ${ }^{35}$; y a la vez que negaba que su obra fuese un simple inventario o catálogo, afirmaba que se trataba de apuntes «d'après mes vues», de un cuadro pintado bajo diversas fases y trazado tal como salía de su pluma a medida que sus ojos y entendimiento reunían las partes ${ }^{36}$.

Para captar esa multiplicidad de aspectos - de la gran capital o del país-, en obras francesas posteriores se multiplicará el número de autores, con el resultado, como sabemos, de un «drame» o una «comédie» con «cent actes divers». ¿Qué contraste con la «prodigieuse étendue de tête» de Richardson, tan admirada por Diderot por ser capaz él solo de «conduire de drames de trente à quarante personnages»! Los promotores mismos de tales publicaciones fueron conscientes de que su pretendida unidad se re-

${ }^{34}$ El rastreo de recursos tendentes a la trabazón ha seguido dos líneas, abiertas ambas por una misma monografía sobre Mesonero: la de Romero Tobar (1983). A partir del registro que éste hace de la técnica de reaparición de personajes (256), Palomo (1989: 233) ha apuntado al "posible entramado novelesco de una parte de las Escenas» y a la «visión global de la comedia humana» - la propia de mundos novelescos como los de Balzac y Galdós- a que Mesonero «aspira». En cambio, para Baker (1991: 65-68) «es más espacial que temporal y narrativa» la labor ensambladora del costumbrista, cuyos conjuntos pone en relación con los panoramas pictóricos y no con las estructuras novelísticas: el factor estructurante lo proporciona la seudonimia, «la máscara del escritor costumbrista», dicho con palabras de Romero Tobar (254).

35 «Que de tableaux éloquens qui frappent l'oeil dans tous les coins des carrefours, $\&$ quelle galerie d'images, pleine de contrastes frappans pour qui sait voir \& entendre» (Mercier, 1781: I, p. 6).

${ }^{36}$ «Je n'ai fait ni inventaire ni catalogue; j'ai crayonné d'après mes vues; j'ai varié mon Tableau autant qu'il m'a été possible; je l'ai peint sous plusieurs faces; \& le voici, tracé tel qu'il est sorti de dessous ma plume, à mesure que mes yeux \& mon entendement en ont rassemblé les parties» (Mercier, 1781: I, pp. VI-VII). 
sentía ${ }^{37}$. Problema éste del que no estaban exentos ni siquiera las conjuntos de artículos de un único autor. Eran, por más que pretendiesen recorrer toda la sociedad, representaciones fragmentarias sin una estructura - amplia y holgada, pero unificadora - como la de una novela. En ese caso se encontraba Mesonero.

\section{ARtículos de costumbres y nOVela en el discurso De Mesone- RO: MÍMESIS DE TODA LA SOCIEDAD Y UNIDAD DE LA OBRA}

Los planteamientos de los costumbristas foráneos obtuvieron eco en España. Sólo con acudir a algunos tempranos textos exhumados por José Escobar (1977a y 1977b) en estudios suyos dedicados a rastrear las huellas de Mercier y de Jouy, se podría probar la incidencia entre nosotros de estas ideas de que me vengo ocupando: una, la penetrante mirada del escritor costumbrista, capaz de mostrar cosas que, a fuerza de verse todos los días, pasan inadvertidas, matices o circunstancias que, por fugitivos, escapan a la percepción habitual; otra, la ciudad como vasto campo para el observador atento a las costumbres sociales.

El primer tópico, además de con la labor de los autores de cuadros de costumbres, se puso también en relación - muy tempranamente por parte de Diderot- con la de los novelistas ${ }^{38}$. De forma que, si se puede alegar el deseo de Mesonero de «observar y leer en el gran libro del mundo» (1832, en Escobar, 1977b: 19), si se puede aducir su identificación con el Diablo Cojuelo, con la que quiere ponderar su capacidad de registro de escenas «cuya observación se escapa a la mayor parte de los testigos» ([1833] 1967: I, 189b), de igual modo pueden alegarse juicios de críticos españoles sobre la intensidad de la mirada literaria desplegada en las novelas de costumbres: por eso, una obra de esa clase "puede impresionarnos con más viveza que el espectáculo ordinario y frío de las costumbres

${ }^{37}$ Éste fue el argumento para justificar la multiplicidad de colaboradores en Paris, ou le livre des Cent-et-un: «si l'unité y perd, l'intérêt y gagnera» (1831: I, 15).

${ }^{38}$ Escobar ha estudiado la influencia del Tableau de Paris (1781) de Mercier en un artículo programático de 1828 , cuyo autor desconocido dice que no deja de «observar con meditación todo lo que está a la vista y aun algo de lo que no se ve» (1977a: 33). También ha probado Escobar las deudas de un artículo de Mesonero - «Costumbres. El Curioso Parlante» (1832) - con el «Portrait de l'auteur» antepuesto por Jouy a L'Hermite de la Chaussée d'Antin, donde declara su propósito de recoger «une foule de détails domestiques, de circonstances fugitives» (apud Escobar, 1977b: 8). Advierto que ya se había referido Diderot en 1752 a la "circonstance fugitive» - vid. la nota 24- que es capaz de mostrar el arte del poeta y del pintor, y había aplicado a la novela un argumento reiterado luego por Jouy y Mercier. De éste último puede alegarse esta declaración al frente de su Tableau de Paris: «Je me suis attaché au moral \& à ses nuances fugitives» (1781: I, p. VI). 
mismas» (Forteza, 1857: 11); por eso, la novela «nos convierte en observadores, hácenos ver lo que diariamente pasa delante de nuestros ojos, desapercibido antes para ellos» (Fernández Espino, 1857: 7).

Y la aspiración a una mímesis de toda la sociedad la hacen pública unos y otros. Mesonero la proclamó a lo largo de toda su trayectoria: desde un temprano artículo programático de 1832 — «Costumbres. El Curioso Parlante»- y el prólogo suyo al Panorama matritense (1835), que repite la propuesta de ese artículo, hasta un pasaje de sus Memorias, que vuelve a reproducir en el prólogo de la edición de su obra de 1881. «Tal es el plan que me propuse, abrazando en la extensión de mis cuadros todas las clases», declaró en el primer texto, si bien reconocía a la vez que la que obtenía lugar preferente era la clase media, ya que, "por su extensión, variedad y distintas aplicaciones, es la que imprime a los pueblos su fisonomía particular» (en Escobar, 1977b: 20; son míos los subrayados). Y en sus Memorias señalará esta ventaja de su plan de pintura social por medio de artículos: "por su variedad sin límite obligado, me permitía recorrer a placer todas las clases [...] la sociedad, en fin, bajo todas sus fases» (1967: V, 188a, y 1994: 430; el subrayado es mío).

La serie como fórmula para realizar todo un recorrido - recurso ya presente en los primeros pasos de Mesonero como costumbrista ${ }^{39}$ - le permitía, por tanto, superar las limitaciones del artículo breve y suelto. En este sentido, podía competir con los frescos sociales de las novelas. La extensión del vehículo o bien su expansión - de ahí la dilatación también del cauce novelesco a través de trilogías u otras series- favorecía una amplia mímesis de toda la sociedad. El escritor de costumbres debía frecuentar, en opinión de Larra, «las clases todas de la sociedad» (1960: II, 242a). Y un novelista como Ayguals de Izco declaraba, al frente de María la hija de un jornalero, el primer título de su trilogía, que su propósito era «describir las costumbres de todas las clases del pueblo» (1845: I, 6). Aunque en muy distinto campo ideológico, Fernán Caballero se presentó asimismo como novelista de un extenso panorama social, si bien era en el pueblo - andaluz - en donde veía la encarnación de lo genuino español ${ }^{40}$.

Repárese en la equivalencia establecida, tanto por Mesonero como por Fernán, entre el todo social y una de sus partes. Se trata de una operación metonímica en que la representación de la totalidad de la sociedad españo-

\footnotetext{
${ }^{39}$ Sobre su folleto Mis ratos perdidos (1822), recordará en Memorias de un setentón: «borrajeé una serie de doce artículos de costumbres (uno para cada mes del año 1821), en que, preludiando ya mi natural instinto de observación satírica, me propuse trazar cuadros festivos de la sociedad que apenas conocía» (1967: V, 121a, y 1994: 317).

${ }^{40}$ No obstante esa preferencia, no se olvide que, al iniciar La gaviota su andadura en el folletín de El Heraldo (9-V-1849), una nota prometía otras tres novelas con las que Fernán completaría la serie de Los españoles pintados por sí mismos y en las que pintaría el pueblo, la clase media y la sociedad «como existía hace treinta años».
} 
la se hacía descansar en una clase por encarnar ésta más cabalmente la originalidad nacional frente a otras colectividades. La propuesta burguesa de Mesonero hacía coincidir los conceptos de nación y clase media (Kirkpatrick, 1978: 32-34). Pero Mesonero no fue el único en pronunciarse sobre la mímesis de la clase media. Otros - Gómez Hermosilla y Neira de Mosquera - se anticiparon al Galdós de las Observaciones sobre la novela contemporánea en España (1870; vid. ed. de 1972: 122-124), al asociar esa mímesis con el género novelesco ${ }^{41}$. Estos rastreos no deben hacernos olvidar la procedencia europea de los textos fundadores de la mímesis costumbrista, con la que se imponía «la logique de la classe mitoyenne», dicho sea con expresión de Mercier - Du Théâtre - glosada por José Escobar (1988a: 265) ${ }^{42}$.

Era una mímesis realista en la que se conciliaba, como ya hemos visto, el particularismo con la ambición de totalidad. A su servicio se podía poner una pieza breve - los artículos-, pero susceptible de expandirse por medio de la serie. Adviértase el paralelismo de los argumentos con que Mesonero defiende su objeto preferente de mímesis social - una clase, la media- y su elección genérica —unos textos fragmentarios, los artículos-: en ambos casos, se refiere a su variedad y extensión. Gracias a estas notas cobraban valor mimético abarcador de la totalidad tanto un objeto como un vehículo parciales.

Esos movimientos de vaivén entre el todo y la parte afectaban no sólo al plano social. Fernán Caballero reiteró su deseo de escribir novelas de costumbres no ya de cada nación, sino hasta de cada provincia y localidad, en cuya descripción se combinasen los aspectos materiales y los morales ${ }^{43}$. Ambas facetas de Madrid, material y moral, se había propuesto pintarlas Mesonero a través de obras distintas: así se justificó en 1835 en el prólogo a su Panorama matritense (1987: 349); y, más tarde, también

\footnotetext{
${ }^{41}$ Álvarez Barrientos (1991a: 383-384 y 1991b: 51-52) ha llamado la atención sobre la novedad, a este respecto, del Arte de hablar en prosa y verso (1826) de Gómez Hermosilla. Aunque se trata de una preceptiva, quiero precisar que es en el apartado sobre la historia de la «historia ficticia», que no en el de sus reglas, donde, al abordar las «novelas familiares» tal como se cultivaban en Inglaterra, se constata este hecho: «Se presentaron personajes de la clase media de la sociedad» (1826: II, 85). Mayor valor, por ser ahora prescriptiva, es la propuesta de Neira de Mosquera sobre la novela moderna española que registró hace ya muchos años Sherman Eoff (1940: 536-537). Cito a Neira (1848: 187): «Los verdaderos hábitos del pueblo español deben ser examinados en la clase media y en la sociedad acomodada».

${ }^{42}$ Vid. Álvarez Barrientos (1990: 239-240) sobre el eco en la España del XVIII de la propuesta de Diderot - Entretiens sur le Fils Naturel- de una mímesis teatral de las personas de la nueva clase media. Sobre la lógica de esa clase en Bretón, remito a Escobar (1994: 201-202).

${ }^{43}$ Véase la propuesta que, a este respecto, hace un personaje de La gaviota (1849) en el célebre capítulo IV de su segundo tomo (ed. 1972: 306); remito también a La estrella de Vandalia ([1855] 1961: III, 98).
} 
en sus Memorias, donde confesó que su proyecto de descripción costumbrista abarcaba la sociedad bajo todas sus fases, lo mismo exteriores que privadas (1967: V, 188a, y 1994: 430-31). Ese afán de totalidad fue el que llevó a Ayguals a presentar su María como obra de intención social, descripción de las costumbres madrileñas y auténtica historia contemporánea (1845: I, 6-7) ${ }^{44}$. Y en el epílogo de La marquesa de Bellaflor, se declaró «deseoso de patentizar el verdadero estado de civilización de España en la descripción de las costumbres de su capital» (1847: II, 615).

Se opera de nuevo un proceso de focalización metonímica, por el que un determinado marco espacio-temporal absorbe la nación entera; proceso en el que el papel que desempeñaron los costumbristas en los años treinta del XIX fue de protagonistas (Romero Tobar, 1994: 398-399). En el artículo «Las costumbres de Madrid» (1832), con que abre su Panorama matritense -obsérvese la conjunción de focalización local y horizonte abarcador-, Mesonero ya dejó expuesto su propósito de «presentar al público español cuadros que ofrezcan escenas de costumbres propias de nuestra nación, y más particularmente de Madrid, que, como corte y centro de ella, es el foco en que se reflejan las de las lejanas provincias» (1967: I, 39).

Tras el registro de planteamientos en que convergían Mesonero y novelistas coetáneos de él, no hay que olvidar que Mesonero rechazó las modas novelescas imperantes en su tiempo. Su motivo: la defensa de una mímesis de lo ordinario, contraria a lo extraordinario y raro, esto es, a lo excepcional y sin valor representativo del común de la sociedad, valor que sí concedía a la clase media. Esta fue una de las razones con que justificó en 1842 su elección del artículo de costumbres, en vez de la novela y el teatro: no eran tiempos propicios para pintura de la vida en común ni en la escena ni en el libro, pues estaba de moda una sociedad antigua y misteriosa, novelesca e ideal (1987: 352-353). Tampoco salvaba a las obras coetáneas francesas de asunto contemporáneo. Lo extraordinario, complicado y pasional le llevó a condenar «la literatura novelera francesa» (SPE, 16-VIII-1840). Reprochaba a Balzac, Soulié y Sand el retratar en sus ingeniosas novelas «una parte de la sociedad que, como más disipada, se ostenta diariamente con su pomposo aparato de pasiones exageradas», de forma que «las demás afecciones privadas permanecen modestamente ocultas tras de la brillante escena del gran mundo» (1967: V, 341b). En la parcial pintura de las «excepciones» se apoyó su censura moral de novelistas y dramaturgos modernos (1967: II, 164).

En sus críticas de la literatura francesa, Mesonero no se quedó solo.

${ }^{44}$ Con su inserción del folletín a la manera de Sue en un marco español y contemporáneo, Ayguals respondía a la vez a la necesidad de nacionalizar la narrativa foránea y a la exigencia de la novela del día de abarcar toda una sociedad (Ferraz, 1992: I, 563 y ss.). 
Recuerdo, por ejemplo, los pronunciamientos de Fernán Caballero contra lo extraordinario y «romancesco» de las producciones francesas, en oposición a lo cual definió su propia posición estética (vid. Ferraz, 2000: 182183) y bautizó sus obras como «cuadros de costumbres» en vez de como «novelas». Por su parte, Mesonero se felicitaba de que no se correspondiese la sociedad española con la francesa tal como la reflejaban las novelas transpirenaicas (1967: II, 288b, y III, 480b). Y el mismo Larra, en su crítica teatral de Antony, de Alejandro Dumas, al que reprochaba haber erigido un «caso posible, solamente posible, pero siempre raro, en dogma», dirá de la literatura francesa que, al no ser «intérprete de nuestras creencias ni de nuestras costumbres, sólo nos puede ser perjudicial» (1960: II, 249a).

Sin embargo, a pesar de los reparos morales que pudiese poner a la literatura francesa, Larra colocó a la cabeza de los escritores de costumbres a Balzac. Lo admiraba - ya lo he consignado- por haber recorrido el mundo social. El resultado - añado- era el desconsolado conocimiento de la moderna sociedad francesa - «desdichada, asquerosa a veces y despreciable»-, pues en su viaje el escritor había llegado hasta el último confín para terminar viendo «un abismo insondable, un mar salobre, amargo y sin playas, la realidad, el caos y la nada» (reseña del Panorama matritense, 19-VI-1836, en 1960: II, 240b).

En el extremo opuesto se situaba la visión que pretendía ofrecer el costumbrista Mesonero: «festivos bosquejos de nuestras costumbres contemporáneas» llama a sus cuadros en 1842, así como "pintura festiva, modesta y natural» (1987: 351 y 353). $\mathrm{Y}$ en otro momento en que marca distancias con Larra, declara que se proponía «pintar con risueños, si bien pálidos colores, la sociedad privada, tranquila y bonancible, los ridículos comunes, el bosquejo, en fin, del hombre en general» (1967: I, 40b; 1987: 369). No difería de este enfoque el que aplicó a la novela de costumbres, o «pintura sencilla de los usos populares, de los caracteres comunes en la sociedad» (1839: 254a, y 1883: 35), en cuya definición se valió -lo que subraya su concepción paralela de ambos géneros- de notas análogas a las empleadas para los artículos de costumbres (remito a la nota 9).

Los adjetivos de todas estas citas no hacen sino poner de relieve una interpretación o visión personal de la realidad (Shaw, 1996), cuya representación respondía a una concepción ideológica (Escobar, 1988b: 58). Sabemos que Mercier había negado que su obra se redujese a un inventario: antes bien, consistía en sus impresiones de las costumbres parisienses. Y por lo que respecta a las propuestas miméticas de diversos autores españoles no sólo de artículos sino también de novelas de costumbres, repetidas veces he tenido la ocasión de comprobar que podían moverse entre muy variadas, y aun opuestas, fuerzas de tensión (Ferraz, 1992: I, 588 y ss.: 1996: 149-153).

Se explica así por qué Mesonero no vio en la novela de Balzac un 
modelo para recorrer, como decía Larra, la sociedad moderna, mientras que la obra que le seducía - y en esta atracción no fue único en su épocaera el ya lejano Gil Blas de Lesage, donde se pasa revista a toda una sociedad y época (vid. Ferraz, 1992: I, 329-334). Buscaba Mesonero un molde capaz para poder pintar el Madrid moral «con toda la extensión que cumplía a mi propósito», recuerda en sus Memorias, pero, a renglón seguido, alega que ya no podía contar con la novela satírica de costumbres al corte de la de Lesage, dado que «estaba enterrada entre nosotros hacía dos siglos» (1967: V, 187a, y 1994: 429; el subrayado es mío). En esas mismas páginas, además de admitir las limitaciones del teatro para un recorrido por todas las clases, se excusó diciendo que «no podía competir tampoco con la gracia, la espontaneidad y galanura del insigne Bretón [de los Herreros]» (1967: V, 187b, y 1994: 429), coetáneo suyo en cuya obra podía reconocer una continuidad con la comedia de costumbres y los sainetes del XVIII. Con la mirada amable de estos géneros, que no con la visión amarga que Larra descubrió en Balzac, es con la que cuadraban los adjetivos con los que Mesonero hizo antes explícita su orientación mimética.

En definitiva, si Diderot sí vio en las novelas de su coetáneo Richardson cumplidos los valores del concepto de imitación moderno, razón por la que las relacionó con el drama burgués, a Mesonero, en cambio, sus afinidades y gustos literarios, así como su particular posición ideológica, al tiempo que le llevaban a declarar su estima por el teatro de Bretón, le impedían valorar la función mimética de la moderna novela francesa de su época, a la que acusaba de escoramiento hacia lo extraordinario y parcial; es decir, a la que situaba en oposición a una mímesis de lo común, que se venía tradicionalmente asociando con la comedia ${ }^{45}$. Llamo ahora la atención sobre el hecho de que su antes citada definición de la novela de costumbres - pintura de «los caracteres comunes de la sociedad»- puede interpretarse como contramodelo de la novela francesa y como prueba de una orientación mimética compartida con la comedia, tal como la entendía Moratín ${ }^{46}$.

${ }^{45}$ Aunque no sólo con ella. La definición que en el XVIII hace el Diccionario de la Real Academia de «Novela» reza: «Historia fingida y texida de los casos que comúnmente suceden, o son verosímiles». La recojo de François Lopez (2000: 476 y 499), que subraya la amplitud indiferenciadora de tal definición (cfr. la de «Comedia» en el mismo Diccionario, citada también por Lopez, 2000: 475).

${ }^{46}$ Ya señaló Sebold (1981: 339 y ss.) deudas de Mesonero -el concepto de teatromundo y el uso de terminología teatral en sus cuadros- con la comedia de filiación dieciochesca. Y Álvarez Barrientos (1994) ha puesto de relieve que, en el discurso crítico de Mesonero sobre el teatro, los objetivos que le asigna son los mismos que los del cuadro de costumbres y la novela. Por mi parte, con la siguiente cita, quiero mostrar las coincidencias de los planteamientos de Mesonero con los de Moratín: «En la comedia todo es diferente [a la tragedia]: acciones domésticas, caracteres comunes, privados intereses, ridiculeces, errores, defectos incómodos en una determinada sociedad; eso pinta de estos materiales compone sus fábulas. Expone a los ojos del espectador las costum- 
Con él también coincidía Mesonero en ser bien consciente de la historicidad de su pintura de las costumbres. Si las circunstancias incidían en la recepción de una obra teatral —así lo reconocía Moratín (1970:73)—, en el caso de los artículos sueltos, cuya escritura nacía ligada a la periodicidad de la prensa, su fragmentarismo acentuaba, multiplicándolo, el fenómeno: «como estas ligeras obrillas suelen ser hijas de las influencias del momento en que se publican» - admitía Mesonero en una declaración en que me parece oír el eco de Mercier- «por muy independiente que sea [su autor] de las circunstancias públicas, escribiendo en diversas épocas, bajo distintas impresiones, ha de revelar forzosamente la marcha de los sucesos, y hasta los de su propia edad; por eso es preciso que los lectores tomen en cuenta la fecha de cada cuadro, y se trasladen, si es posible, con la mente al punto de vista en que les colocó el pintor» (1987: 353).

Esta cita de Mesonero corresponde a su introducción de 1842 a las Escenas matritenses, donde relacionaba, como ya apunté, tres géneros -el teatro, la novela, los artículos- a los que afectó el cambio del concepto de imitación. No sólo merece ser tenida en cuenta esta interrelación; asimismo, dado que todo sistema, amén de comunión, implica diferencias, el que apuntase entonces a ellas al designar tales géneros por medio de sus vehículos - la escena, el libro, el periódico-, pues, aunque éstos canalizasen creaciones con similar propósito mimético, no podían sino condicionar su estructura y forma de comunicación. La oposición tradicional novela/teatro se enriquece ahora con la entrada de un tercer elemento innovador: el artículo canalizado a través de la prensa, que, frente al libro, contrastaba por su brevedad y fragmentarismo. Mesonero justificará su elección en sus Memorias de un setentón como sigue: «preciso era inventar otra cosa que no exigiese la lectura seguida de un libro, sino que le fuese ofrecida [al público] en cuadros sueltos e independientes» (1967: V, 188a, y 1994: 430; el subrayado es mío).

Aunque la serie «sin límite obligado» le permitía solventar la constricción del cuadro aislado, a Mesonero, buen conocedor de las colecciones extranjeras, no se le ocultaron las limitaciones de unas obras formadas - decía ya en 1835 - «de artículos sueltos y sin la trabazón de una seguida novela» (1987: 348; el subrayado es mío). Por eso, siete años después, en 1842 , a pesar de aducir como ventaja de los artículos que acaso interesa-

bres populares que hoy existen, no las que pasaron ya; las nacionales, no las extranjeras; y de esta imitación, dispuesta con inteligencia, resultan necesariamente la instrucción y el placer. Pero es muy grande la dificultad de pintar las costumbres del día con la gracia, la semejanza, la delicadeza, el arte y atinada elección que se necesitan para el acierto; y el juez ante quien debe presentarse un remedio de tal especie, como tiene perfecto conocimiento del original, echa de ver inmediatamente los defectos en que ha podido incurrir el artífice» (Moratín, 1970: 198-199). Esta orientación mimética es compartida asimismo por don Ramón de la Cruz (vid. nota 26). 
rían más «por lo incisivo del pensamiento y su marcha desembarazada de obstáculos» ${ }^{47}$, reconocía que producciones de tal género no podían presentarse subordinadas todas «a un pensamiento común»; aún más, entrando en el terreno personal, confesaba que «su pensamiento primitivo fue el de escribir una obra de costumbres contemporáneas [...] sujetándola a una sola acción, dándola la extensión conveniente», pero que las tendencias del día, contrarias a tal pintura en la novela, y aun en el teatro, le obligaron a desistir y a «reducir a simples bocetos los varios episodios del cuadro que tenía imaginado, renunciando a la ventaja de presentarlos reunidos en un solo grupo y subordinados a una acción simultánea» (1987: 353-354; los subrayados son míos).

Mesonero, partícipe de la aspiración abarcadora del novelista, estaba tocando una cuestión disputada: la de unidad de la novela y el papel que en ella podían desempeñar los episodios e historias ${ }^{48}$. Ese debate enlazaba con la clásica oposición, en razón de la capacidad de la epopeya para el desarrollo episódico, entre ese género narrativo y la representación dramática. De ahí que Hartzenbusch, cuando, en el prólogo a la edición de 1851 de las Escenas Matritenses (p. II), abordó el asunto de la unidad y multiplicidad de los artículos de Mesonero, adoptase la perspectiva del poema (épico), para de esta suerte conjugar ambas. Hartzenbusch negaba que el costumbrista madrileño hubiese escrito «una colección de obrillas sueltas», en lugar de una obra cuyo héroe, aunque no saliera de entre bastidores, era «el español virtuoso, noble y sabio de ahora, igual casi al de todos tiempos». Éste era su razonamiento: Mesonero «saca sólo a las tablas aquellos personajes cuyas costumbres necesitan enmienda, las cuales forman los numerosos episodios de este poema: aun en los poemas clásicos valen más los episodios que la acción principal».

Por las fechas en que escribía Hartzenbusch, el tomar directamente como punto de apoyo el poema épico, para así dar explicación de la obra costumbrista de Mesonero, resultaba extemporáneo ${ }^{49}$. Otros eran los géneros po-

${ }^{47}$ El argumento del interés ya se había utilizado en la colección Paris, ou le livre des Cent-et-un (remito a la cita de la nota 37).

${ }^{48}$ Firmes defensores de la unidad de acción, que propugnaban evitar lo episódico, se habían mostrado, por ejemplo, un novelista como Mor de Fuentes y un preceptista como Gómez Hermosilla (Álvarez Barrientos, 1991a: 292 y 382; 1991b: 50), mientras que para Marchena Marchena la única unidad que la novela debía respetar era la de interés, por lo que admitía variedad de episodios e historias paralelas (Álvarez Barrientos, 1991a: 378-380; 1991b: 46-48). Añado un texto más cercano a los de Mesonero que comento: Alcalá Galiano (1838: I, 53), aunque reconocía que «entre las tres unidades la llamada de acción es la de más importancia», opinaba que «aun con episodios inconexos, y hasta sin tener verdadera y única acción puede entretener y suspender una novela o un drama», pues la unidad imprescindible era la de interés.

${ }^{49} \mathrm{La}$ epopeya había sido punto de referencia para la novela. En su Lettre-traité sur l'origine des romans, Pierre-Daniel Huet, a partir del contraste con el poema épico, elu- 
tenciados por la mímesis moderna para la representación de la vida social, cuyo protagonista era —en palabras de L-S. Mercier ( $D u$ Théâtre)«l'honnête bourgeois» (apud Escobar, 1988a: 264). Había sido del drama moderno de donde había partido la reflexión generadora del nuevo concepto imitación. Era ese género el que había enriquecido el concepto diderotiano de novela como maridaje entre la extensión - antes asociada a la epopeya- y la mímesis realista propia de aquel. Por eso, con su declarado propósito de reunir en sus cuadros «las condiciones principales de la novela y del drama» (1967: V, 188a, y 1994: 430), Mesonero se situaba, en contraste con Hartzenbusch, en un marco de relaciones genéricas más propio de la modernidad.

También se planteó en época de Mesonero si era posible un proceso que, partiendo de los cuadros de costumbres, condujese a la novela; enfoque que manifiesta una concepción de la obra novelesca como tejido o mosaico compuesto a partir de elementos diversos. De entonces es la apreciación crítica de los artículos de Mesonero y de sus imitadores «como bocetos parciales que luego han de formar un conjunto armónico y prolijamente acabado. [...] Aquí está el embrión de la futura novela contemporánea, que da muestras de querer desarrollarse con vigor» («Novela española», El Español, 8-VI-1845, p. 4b; el subrayado, con el fin de facilitar la comparación con el texto de Mesonero de 1842 hace poco citado, es mío). Este planteamiento lo desarrollaría después Galdós valiéndose del cuento - ya con movimiento - como eslabón entre los cuadros y la novela ([1870] 1972: 124). Ya antes, Antonio Flores había intentado saltar al entramado novelesco en Doce españoles de brocha gorda (1846): la relación entre los tipos había sido - decía - «la causa de que los cuadros aparezcan ligados entre sí» (1846: 286). Pero no todos dieron por válido el resultado: no era una novela, según Ochoa, sino una «colección de artículos mal enlazados entre sí para formar, no sin violencia, una acción seguida» (en Flores, 1857: 277b).

El mismo Mesonero, pasados los años, declaró en «Adiós al lector» (1862), texto que puso al frente de Tipos y caracteres, que deseó ir más allá de la escritura de artículos sueltos, pues, aunque luego se hubiesen agrupado -el Panorama y las Escenas matritenses-, estos libros habían nacido «sin preexistente intención del escritor»: por tanto, «quiso dar otro giro a sus tareas, y [...] aspiró a generalizar más en una tercera obra la pintura satírico-moral de las costumbres y caracteres contemporáneos, no precisamente contraídos a la localidad de la capital, sino abarcando la generalidad de la sociedad moderna española»; sin embargo, su proyecto no cuajó: «su modesto pincel se resistió a trazar más importante obra; su óptico

cidó los caracteres de la novela, entre ellos, su mayor capacidad episódica (Huet [1669] 1971: 47-48). 
instrumento no acertó a verse libre del propio modelo objetivo, y Escenas matritenses le brotaba obstinadamente su pincel» (1967: II, 201-202).

Puesto que Mesonero se fijaba metas análogas a las que podían perseguirse en una novela - la visión panorámica de la sociedad y su canalización en un libro u obra unitaria-, no sorprenderá que su declaración de 1862 haya sido interpretada como público reconocimiento de su incapacidad para ese género, al que ya desde una muy temprana edad había aspirado, según recuerda en sus Memorias, donde a la vez reconoce realizado su propósito infantil en uno de los Episodios de Galdós (1967: V, 89-90, y 1994: 253-54). «Adiós al lector», apuntase a la novela - referencia, desde luego, no explícita- o antes bien a una obra de naturaleza muy diferente ${ }^{50}$, constata en todo caso la permanencia, a lo largo de los años, de unas mismas preocupaciones.

En cuanto al alcance de su pintura, si en 1862 confesaba Mesonero haber deseado abarcar «la generalidad de la sociedad española», en su discurso de 1838 ya había dicho que la novela alcanzaba valor sumo cuando conseguía «formar el cuadro general de una época marcada en la historia de cada país» (súmense a éstos los textos arriba citados a propósito de su ambición mimética de cubrir toda la sociedad). Y por lo que hace a los límites del vehículo empleado, si en 1862 reconocía que sus artículos, por más que luego se hubiesen recolectado en libro, carecían de previa concepción como tal, en 1842 había admitido su carácter fragmentario al justificar por qué la pintura de costumbres «tuvo, pues, que abandonar por un tiempo determinado, el libro y la escena; tuvo que refugiarse en el periódico y subdividirse en mínimas partes para hallar todavía auditorio»; y añadía Mesonero que hasta Cervantes, si hubiera escrito entonces, «hubiérase visto precisado a reducir sus cuadros a esas pequeñas proporciones» y sólo habría conseguido lectores de su inmortal novela «dispensándoles sus capítulos a guisa de folletín» (1987: 353; el subrayado es mío) ${ }^{51}$.

El supuesto cervantino tenía como fin apoyar el recurso, en vez de a

${ }^{50}$ Las interpretaciones de ese artículo han sido contrapuestas. La visión antinovelesca que Montesinos tiene de Mesonero no hace sino reforzarse: «señala el creciente predominio de lo discursivo en sus cuadros», dictamina, para a continuación recordarnos con cita textual que Mesonero «en vano pidió a la ciencia nuevos recursos para dar mayor importancia, forma diversa, a sus estudios sociales», es decir a esa tercera obra, que «no se hizo, como tampoco se hizo la famosa novela» ([1960] 1965: 52). Los interesados en las virtualidades novelescas de Mesonero han identificado ese proyecto abarcador con el anhelo -eso sí, también frustrado- de escribir una novela (Palomo, 1989: 233; Escobar y Álvarez Barrientos, 1994: 25 y 54-55).

${ }^{51}$ En las Memorias el folletín será sustituido por las entregas: tuvo que recurrir a cuadros sueltos e independientes - confiesa - «valiéndose de la prensa periódica, que es la dominante en el día, porque el público gustaba ya de aprender andando, y todavía tampoco se le había acostumbrado a endosarle las páginas del libro por debajo de las puertas, en entregas o pliegos sueltos» (1967: V, 188a, y 1994: 430). 
géneros más prestigiados, a los artículos en razón de los hábitos de lectura propiciados por la prensa periódica. Repárese además en que su elección la presentaba Mesonero - en paralelo con tal supuesto- también como una operación reductora (reitero la cita y subrayo: «reducir a simples bocetos los varios episodios del cuadro que tenía imaginado»). Se trataba de procesos en dirección contraria al que llevaría de los cuadros a la novela como obra con trabazón interna - novela que, no obstante, seguía, si bien en negativo, siendo punto de referencia- y asimismo al libro como vehículo unificador que posibilitaba una forma de recepción seguida, distinta a la discontinua de la prensa ${ }^{52}$.

En la estimación de Mesonero pesaba el prestigio tradicional del libro. Lo confirma su confesión en 1862 de que aspiraba a «dar mayor importancia, forma diversa a sus estudios sociales» con su proyecto de una tercera obra concebida «bajo el plan de un edificio aislado e independiente» (1967: II, 202). En este punto, no está de más destacar que, en ese frustrado proyecto a que Mesonero se refiere, van unidas la idea del libro y la de la ampliación del campo, mientras que con los artículos asocia el carácter local y circunstancial, así como su concepción suelta. Conjugar en una obra unitaria la mímesis de lo particular junto con la ambición de plenitud o totalidad era el reto de la novela moderna. En este sentido, sí puede decirse que el texto de 1862 , al presentar caminos separados, sin confluencia, es la confesión del paso que no dio Mesonero.

$\mathrm{Su}$ recurrente tensión entre aspiraciones y realidades - no reducida a ese texto- ha contribuido a dar de él una imagen de novelista frustrado. Más interesante juzgo el que sus reflexiones se situasen en el marco de un sistema de géneros. De ahí que, mediante un juego de convergencias y oposiciones, caracterizase el artículo de costumbres entre la novela y el teatro. Y de ahí que, al situar su discurso en el cuadro teórico de los siglos XVIII y XIX, podamos nosotros lograr una comprensión más cabal de las conceptos en torno a esos tres géneros.

\section{CIERRE CON APERTURA: GÉNEROS MIMÉTICOS Y REALISMO}

Mesonero fue consciente de que los tres géneros - afectados por el nuevo concepto de imitación del XVIII- compartían un mismo objeto: la sociedad presente y circundante. $\mathrm{Y}$, respecto al modo de imitación, se valió, como otros, de un criterio aristotélico - la oposición entre tragedia y epopeya - transferido a la (re)presentación teatral y al relato novelesco;

${ }^{52} \mathrm{Si}$ se contrasta la referencia a las entregas de las Memorias - nota anterior-con la del texto de 1842 —el folletín-, se notará que éste último se presenta como un proceso de fragmentación, mientras que las primeras no dejan de asociarse con el libro en el que desembocarán. Son muy distintas las valoraciones que parecen desprenderse. 
dicotomía que no cuestionaba radicalmente el modo mixto, del que, según Mesonero - vid. las notas 8 y 9-, participaban la novela y el artículo costumbrista con su uso de escenas dialogadas. Nuevas perspectivas introdujo con la consideración del canal al sumar a la escena y el libro la prensa moderna. De sus posibilidades, pero también de sus constricciones, da testimonio el discurso de Mesonero, que, al hacer patentes otros límites propios - su personal enfoque, más acorde con la amable comedia que con la conflictiva novela del día-, prueba, una vez más, que la imitación no se entendía de una única manera, que existían distintas soluciones miméticas.

Comunión y diferencias son las dos caras de todo sistema. En un marco de ese tipo sitúa Mesonero sus artículos, pues los caracteriza en relación con aquellos otros géneros con los que conformaban un abanico de opciones miméticas. Más aún, Mesonero no sólo no ve esos géneros miméticos aislados, sino que además percibe, a propósito de la novela y el artículo de costumbres, el carácter híbrido de la literatura moderna. El hibridismo ya había hecho innovador acto de presencia en la noción diderotiana de novela como amplio drama, pues en ella se aunaban los valores de la extensión y la intensidad, el vasto alcance del campo abarcado y la sensación de plena realidad que proporcionaba la penetrante mirada del novelista. El realismo basado en el detalle no dejaba de ambicionar una visión plena y total de la vida; ambición que asimismo movió a los escritores de costumbres.

Más allá de sus diversas orientaciones, las propuestas de unos y otros tienen la virtud de revelarnos el proceso de mímesis como una operación metonímica, por la que se buscaba alcanzar el todo de la realidad social a través de una parte, fuera ésta una clase social o un marco espacio-temporal. Dicha focalización se completa con un movimiento amplificador y de expansión no sólo en cuanto al sentido: recuérdese la correspondencia apuntada por Diderot entre ilusión de realidad y profusión de detalles gracias al amplio cauce de la novela, así como su defensa, frente a quienes reprochaban la pintura de lo común y lo que se ve a diario, del poder de revelación de la mirada del escritor, al que identifica con los grandes poetas, capaz de descubrir una realidad inadvertida. La misma tesis defendieron Mercier y otros costumbristas al proponerse mostrar realidades que, a fuerza de verse, ya no se percibían, puntos de vista inesperados y nuevos.

Tales declaraciones se emparentan con otras hechas a lo largo de la historia a favor de una literatura «realista»: ideal interpretado por Fernando Lázaro ([1969] 1976: 137-141) como principio dinámico de la serie literaria que orienta en la búsqueda de novedades — realidades infrecuentes, pero también perspectivas insólitas y variaciones de estilo- y que se somete a la ley del extrañamiento. Planteamientos como los de Diderot y Mercier abrían un portillo en el muro de defensa de la mímesis como imitación de lo común y ordinario opuesta a lo nuevo y extraordinario, esto 
es, a los pilares de aquel otro discurso crítico que era partidario de las «historias ficticias» y defensor de la novela como terreno de la poesía, la imaginación y lo ideal (vid. Ferraz, 2000). Estaban recurriendo todos a un mismo argumento: el de la novedad. Y al hacerlo así los primeros, perfilaban un concepto más profundamente «realista» de mímesis. La realidad ordinaria podía ocultar un mundo nuevo, que no era preciso buscar aparte. Misión del escritor-poeta era dar esa vuelta de tuerca.

\section{BIBLIOGRAFÍA CITADA}

\section{TEXTOS}

a) DE RAMÓn DE MESONERo Romanos:

- 1839. «La novela», Semanario Pintoresco Español, 11-VIII-1839, pp. 253-255.

- 1840. «Las novelitas francesas», Semanario Pintoresco Español, 16- VIII-1840, pp. 261-263.

- 1881. «Prólogo para esta edición», en Panorama Matritense (Primera serie de las Escenas). 1832 a 1835. Por el Curioso Parlante. Nueva edición, corregida y aumentada con notas. Madrid, Oficina de la Ilustración Española y Americana, pp. V-XI.

- 1883. Algo en prosa y en verso inédito. Publicado por sus hijos para conmemorar el primer aniversario de su fallecimiento, Madrid, Librería de Fernando Fe.

- 1967. Obras, edición y estudio preliminar de Carlos Seco Serrano, Madrid, Atlas, 5 vols. (BAE, CXCIX-CCIII).

- 1977. «El Curioso Parlante», artículo que vio la luz en La Revista Española (n. ${ }^{\circ} 2$, 10-XI-1832), reproducido por José Escobar (1977b: 18-20): véase II.- Estudios.

- 1987. Escenas matritenses, edición, introducción y notas de María del Pilar Palomo, Barcelona, Planeta, 1987.

- 1994. Memorias de un setentón, edición, introducción y notas de José Escobar y Joaquín Álvarez Barrientos, Madrid, Editorial Castalia/Comunidad de Madrid.

B) DE OTROS:

ANÓNIMO, «Novela española», El Español, 8-VI-1845, pp. 1-5.

AA. VV., Les français peints par eux-mêmes, Paris, Lecrivain et Toubon, Libraires, y Adolphe Delahays, Libraire-éditeur, [s.a.], 2 vols. (1. ${ }^{a}$ ed.: 1840-1842).

- Paris, ou le livre des Cent-et-un, Paris, Chez Ladvocat, libraire de S.A.R. le Duc d'Orleans, 1831-1834, 15 vols.

AlCalÁ Galiano, Antonio, «Literatura», Revista de Madrid, I, 1838, pp. 41-55.

ARISTÓTELES, Poética, edición trilingüe por Valentín García Yebra, Madrid, Gredos, 1974.

AYGUALS DE IzCO, Wenceslao, María la hija de un jornalero, Madrid, Imprenta de D. Wenceslao Ayguals de Izco, 1845-1846, 2 vols.

- La Marquesa de Bellaflor o el niño de la inclusa. Historia-novela, Madrid, Imprenta de D. Wenceslao Ayguals de Izco, 1846-1847, 2 vols.

BLAIR, Hugo, Lecciones sobre la retórica y las bellas letras. Las traduxo del inglés don Joseph Luis Munárriz, Madrid, Oficina de D. Antonio Cruzado y de García y Compañía, 1798-1801, 4 vols. 
Caballero, Fernán, Prólogo para la publicación de La gaviota en el folletín de $E l$ Heraldo, 9-V-1849.

- Obras, edición y estudio preliminar de D. José M. ${ }^{a}$ Castro y Calvo, Madrid, Atlas, 1961, 5 vols. (BAE, CXXXVI-CXL).

- La gaviota, edición, prólogo y notas de Julio Rodríguez-Luis, Barcelona, Labor, 1972.

DíAZ, Nicomedes Pastor, Obras completas, edición de D. José María Castro y Calvo, Madrid, Atlas, 1969-1970, 2 vols. (BAE, CCXXVII-CCXXVIII).

Diderot, Oeuvres Esthétiques, ed. de Paul Vernière, Paris, Éditions Garnier Frères, 1959.

FERNÁNDEZ DE MORATín, Leandro, La comedia nueva. Comedia en dos actos estrenada en el Teatro del Príncipe. Edición con introduccción, notas y documentos de John Dowling, Madrid, Castalia, 1970.

FERNÁNDEZ EsPINO, José María, 1857. Vid. Forteza.

FORTEZA, Guillermo, De la influencia de la novela en las costumbres. Memoria premiada por la Real Academia Sevillana de Buenas Letras en el certamen público de 1857. Precédela un discurso sobre el mismo tema leído por el Sr. D. José Fernández-Espino en la solemne adjudicación del premio, Sevilla, Francisco Álvarez, 1857.

FLORES, Antonio, Doce españoles de brocha gorda, que no pudiéndose pintar a sí mismos, me han encargado a mí, Antonio Flores, sus retratos. Novela de costumbres contemporáneas, Madrid, Imprenta de D. Julián Saavedra y Compañía, 1846.

Gómez HeRmosilla, Josef, Arte de hablar en prosa y verso, Madrid, Imprenta Real, 1826,2 vols.

HARTZENBuSCH, Juan Eugenio, Prólogo a Escenas matritenses por El Curioso Parlante (D. Ramón de Mesonero Romanos). 5. ${ }^{a}$ edición única, completa, aumentada y corregida por el autor e ilustrada con 50 grabados. Madrid, Imprenta y Librería de Gaspar y Roig, editores, 1851, pp. I-II.

HUET, Pierre-Daniel, Lettre-traité sur l'origine des romans, édition du tricentenaire 16691969 suivie de La lecture de vieux romans par Jean Chapelain. Edition critique de Fabienne Gégou, Paris, Editions A.-G.-Nizet, 1971.

LARRA, Mariano José de, Obras, edición y estudio preliminar de Carlos Seco Serrano, Madrid, Atlas, 1960, 4 vols. (BAE, CXXVII-CXXX).

Lista Y ARAGÓN, Alberto, Ensayos literarios y críticos, Sevilla, Calvo-Rubio y Compañía, 1844, 2 vols.

LUZÁN, Ignacio, La Poética o reglas de la poesía en general, y de sus principales especies. Primera edición completa de ambos textos dieciochescos (1737-1789), ed. Russell P. Sebold, Barcelona, Labor, 1977.

[Mercier, Louis Sebastien], Tableau de Paris, Hamburg, Virchaud \& Compagnie, Libraires, Neuchatel, Samuel Fauche, Libraire du Roi, 1781, 2 vols.

NEIRA DE MOSQUERA, «De la novela moderna», Revista de España, de Indias y del Extranjero, XII, 1848, pp. 181-188.

OCHOA, Eugenio de, «De la novela en España», Revista Hispano-Americana, I, 1848, pp. 271-283.

- Juicio crítico publicado en La España y recogido en apéndice en $F e$, esperanza y caridad, de Antonio Flores, Madrid, Mellado, 1857, tomo II, pp. 277-278.

PÉREZ GALDós, Benito, Ensayos de crítica literaria. Selección, introducción y notas de Laureano Bonet, Barcelona, Península, 1972.

VAYO, Estanislao de Cosca, Voyleano o la exaltación de las pasiones, Valencia, Imprenta de Ildefonso Mompié, 1827, 2 vols. 


\section{ESTUDIOS}

AA. VV., 1996. Romanticismo 6. Actas del VI Congreso (Nápoles, 27-30 de Marzo de 1996). El costumbrismo romántico, Roma, Bulzoni.

ABRAMS, M. H., 1953. El espejo y la lámpara. Teoría romántica y tradición crítica, Barcelona, Barral Editores, 1975.

ÁlVAREZ BARRIENTOS, Joaquín, 1990. «Del pasado al presente. Sobre el cambio del concepto de imitación en el siglo XVIII español», Nueva Revista de Filología Hispánica, XXXVIII, 1, pp. 219-245.

- 1991a. La novela del siglo XVIII, Madrid, Júcar.

- 1991b. «Preceptiva literaria española y novela (1737-1826)», Entre Siglos, 1, pp. 29-56.

- 1994. «Ramón de Mesonero Romanos y el teatro clásico español», Ínsula, 574, octubre, pp. 26-28.

- 1995. «Las Memorias de un setentón de Ramón de Mesonero Romanos y su relación con el género novelístico», Siglo diecinueve (Literatura hispánica), 1, pp. 29-49.

- 2000. «Acreditar el costumbrismo», Ínsula, 637, enero, pp. 3-4.

ÁlvAREZ BARRIENTOS, Joaquín y .ROMERo FERRER, Alberto (eds.), 1998. Costumbrismo andaluz, Sevilla, Universidad de Sevilla.

BAKER, Edward, 1990. «Espacio urbano y representación literaria: Madrid de la Ilustración a la Gloriosa», en Bridget Aldaraca, Edward Baker y John Baverley (eds.): Texto y sociedad: problemas de historia literaria, Amsterdam-Atlanta, Rodopi, pp. 203-213.

- 1991. Materiales para escribir Madrid. Literatura y espacio urbano de Moratín a Galdós, Madrid, Siglo XXI de España.

BENJAMín, Walter, 1972. Iluminaciones II. Baudelaire. Un poeta en el esplendor del capitalismo, prólogo y traducción de Jesús Aguirre, Madrid, Taurus.

CHECA Beltrán, José, 1998. Razones del buen gusto (Poética española del Neoclasicismo), Madrid, CSIC.

COMEllaS AguiRREZÁBAL, Mercedes, 1996. «La reacción antirromántica de Mesonero Romanos», en Romanticismo 6. Actas del VI Congreso (Nápoles, 27-30 de marzo de 1996). El costumbrismo romántico, Roma, Bulzoni, pp. 89-101.

CORREA CALDERÓN, Evaristo, 1950. «Introducción al estudio del costumbrismo español», en Costumbristas españoles, Madrid, Aguilar, 1964 (2. ed.), pp. IX-CXXX.

EOFF, Sherman H., 1940. «The Spanish novel of ideas: critical opinion (1836-1880)», PMLA, LV, pp. 531-558

EsCOBAR, José, 1977a. «Costumbres de Madrid: influencia de Mercier en un programa costumbrista de 1828», Hispanic Review, 45, pp. 29-42.

- 1977b. «El Curioso Parlante en La Revista Española: retrato del autor», Los Ensayistas, II, 4, pp. 5-20.

- 1988a. «La mímesis costumbrista», Romance Quarterly, XXXV, pp. 261-270.

- 1988b. «Narración, descripción y mímesis en el cuadro de costumbres: Gertrudis Gómez de Avellaneda y Ramón de Mesonero Romanos», en Romanticismo 3-4. Atti del IV Congresso sul romanticismo spagnolo e ispanoamericano (Bordighera, 1-11 aprile 1987). La narrativa romántica, Génova, pp. 53-60.

- 1992. «Costumbrismo y novela: el costumbrismo como materia novelable en el siglo XVIII», Ínsula, 546, junio, pp. 17-19.

- 1993. «Ilustración, romanticismo, modernidad», Entre Siglos, 2, pp. 123-133.

- 1994. «Literatura de lo que pasa entre nosotros. La modernidad del costumbrismo», en B. Pallarés, P. Peira y J. Sánchez Lobato (eds.): Sin Fronteras. Homenaje a María Josefa Canellada, Madrid, Editorial Complutense, pp. 195-206.

- 1996. "Costumbrismo. Estado de la cuestión», en Romanticismo 6. Actas del VI Congreso (Nápoles, 27-30 de marzo de 1996). El costumbrismo romántico, Roma, Bulzoni, pp. 117-126. 
- 1998. «Costumbrismo entre Romanticismo y Realismo», en Luis F. Díaz Larios y Enrique Miralles (eds.): Del Romanticismo al Realismo (Barcelona, 24-26 de octubre de 1996). Actas del I Coloquio de la Sociedad de Literatura Española del Siglo $X I X$, Barcelona, Universitat de Barcelona, pp. 17-30.

- 2000. «La crítica del costumbrismo en el siglo XIX», Ínsula, 637, enero, pp. 5-7.

ESCOBAR, José y ÁlVAREZ BARRIENTOS, Joaquín, 1994. «Introducción biográfica y crítica» a la edición de Memorias de un setentón de Ramón de Mesonero Romanos, Madrid, Editorial Castalia, pp. 11-68.

FERRAZ MARTÍNEZ, Antonio, 1992. La novela histórica contemporánea del siglo XIX anterior a Galdós. Madrid, Editorial de la Universidad Complutense de Madrid, 2 vols.

- 1996. «Pintar, retratar, daguerreotipar», en Romanticismo 6. Actas del VI Congreso (Nápoles, 27-30 de marzo de 1996). El costumbrismo romántico, Roma, Bulzoni, pp. 143-154.

- 1998. «Fernán Caballero y el daguerrotipo» (De historia de la fotografía y de estética)», en Estudios de literatura española de los siglos XIX y XX. Homenaje a Juan María Díez Taboada, Madrid, CSIC, pp. 226-235.

- 2000. «La apetencia humana de historias fićticias. Ecos de una tesis de Francis Bacon en el XIX (con una coda del XX)», en Florencio Sevilla y Carlos Alvar (eds.): Actas del XIII Congreso de la Asociación Internacional de Hispanistas. Madrid, 611 de julio de 1998, Madrid, Castalia, II, pp. 177-186.

FERRERAS, Juan Ignacio, 1970. «Novela y costumbrismo», en Introducción a una sociología de la novela española del siglo XIX, Madrid, Edicusa, 1973, pp. 169-194.

GARCía BARRIEntos, José Luis, 2001. Cómo se comenta una obra de teatro. Ensayo de método, Madrid, Síntesis.

GARRIDO GALlARDO, Miguel Ángel, 1988. «Una vasta paráfrasis de Aristóteles», en Teoría de los géneros literarios, Madrid, Arco/Libros, pp. 9-27.

GuILlÉN, Claudio, 1971. «Sobre el objeto del cambio literario», en Teorías de la historia literaria (Ensayos de Teoría), Madrid, Espasa-Calpe, 1989, pp. 199-248.

- 1977. «Cambio literario y múltiples duraciones», en Teorías de la historia literaria (Ensayos de Teoría), Madrid, Espasa-Calpe, 1989, pp. 249-281.

JAUSS, Hans Robert, 1969. «Nachahmungsprinzip und Wirklichkeitsbegriff in der Theorie des Romans von Diderot bis Stendhal», en Nachahmung und Illusion. Kolloquium Giessen Juni 1963 Vorlagen und Verhandlungen, München, Wilhelm Fink, pp. 157178.

KIRKPATRICK, Susan, 1978. «The Ideology of Costumbrismo», Ideologies \& Literature, II, 7, May-June, pp. 28-44.

LÁZARO CARRETER, Fernando, 1969. «El realismo como concepto crítico-literario», en Estudios de Poética (La obra en sí), Madrid, Taurus, 1976, pp. 12-142.

LisSORGUES, Yvan, 1998. «El debate sobre la estética realista», en Víctor García de la Concha (dir.): Historia de la literatura española, vol. 9: Siglo XIX (II), Leonardo Romero Tobar (coord.), Madrid, Espasa-Calpe, pp. 10-18.

LOPEZ, François, 2000. «La institución de los géneros en la España del siglo XVIII», Bulletin Hispanique, CII, 2, pp. 473-517.

MILLER, Stephen, 1980. «Mesonero Romanos y la novela moderna en España», Ínsula, 407, octubre, pp. 1 y 10-11.

- 1983. El mundo de Galdós. Teoría, tradición y evolución creativa del pensamiento socioliterario galdosiano, Santander, Sociedad Menéndez Pelayo.

MONTESINOS, José F., 1960. Costumbrismo y novela. Ensayo sobre el redescubrimiento de la realidad española, Madrid, Castalia, 1965 (2. ${ }^{\text {ed. }}$ e.

PALOMO VÁZQUEZ, Pilar, 1987. Introducción a su edición de Mesonero Romanos, Ramón, Escenas matritenses, Barcelona, Planeta, pp. IX-XLVIII. 
- 1989. «Galdós y Mesonero (una vez más: costumbrismo y novela)», en Galdós. Centenario de «Fortunata y Jacinta» (1887-1987). Actas (Congreso Internacional, 23-28 de noviembre), Facultad de Ciencias de la Información, Universidad Complutense de Madrid, pp. 2.17-238.

ROMERO FERRER, Alberto, 1998. «En torno al costumbrismo del género andaluz (18391861): cuadros de costumbres, tipos y escenas», en Joaquín Álvarez Barrientos y Alberto Romero Ferrer (eds.): Costumbrismo andaluz, Sevilla, Universidad de Sevilla, pp. 125-148.

ROMERO TOBAR, Leonardo, 1983. «Mesonero Romanos: entre costumbrismo y novela», Anales del Instituto de Estudios Madrileños, XX, pp. 243-259.

- 1994. Panorama crítico del romanticismo español, Madrid, Castalia.

RuBio CREMADES, Enrique, 1995. «Costumbrismo. Definición, cronología y su relación con la novela», Siglo diecinueve (Literatura hispánica), 1, 1995, pp. 7-25.

- 1997. «El costumbrismo», en Víctor García de la Concha (dir.): Historia de la literatura española, vol. 8: Siglo XIX (I), Guillermo Carnero (coord.), Madrid, EspasaCalpe, 1997, pp. 153-167.

SAUVAGE, Jacques, 1965. Introducción al estudio de la novela, Barcelona, Laia, 1982. SEBOLD, Russell P., 1979. «Lo romancesco, la novela y el teatro romántico», en Trayectoria del romanticismo español. Desde la Ilustración hasta Bécquer, Barcelona, Editorial Crítica, 1983, pp. 137-163.

- 1981. «Comedia clásica y novela moderna en las Escenas matritenses de Mesonero Romanos», Bulletin Hispanique, LXXXIII, 3-4, juillet-décembre, pp. 331-377.

SHAw, Donald L., 1996. «La pintura... festiva, satírica y moral de las costumbres populares», en Romanticismo 6. Actas del VI Congreso (Nápoles, 27-30 de marzo de 1996). El costumbrismo romántico, Roma, Bulzoni, pp. 299-303.

STIERLE, Karlheinz, 1974. «Baudelaire and the Tradition of the Tableau de Paris», New Literary History, XI, 2, 1980, pp. 345-361.

UCELAY DA CAL, Margarita, Los españoles pintados por sí mismos (1843-1844). Estudio de un género costumbrista, México, El Colegio de México, 1951.

WATT, Ian, 1957. The Rise of the Novel. Studies in Defoe, Richardson and Fielding, Penguin Books in association with Catto \& Windus, 1977. 


\section{RESUMEN}

Entre novela y teatro: el discurso de Mesonero Romanos sobre los artículos de costumbres en el marco de la transformación moderna del concepto de imitación, por Antonio Ferraz Martínez.

Mesonero presentó sus artículos en relación con dos géneros fronterizos: la novela y el teatro. Su discurso se hizo eco de la tradicional oposición aristotélica epopeya/tragedia -mudada en extensión de la novela/intensidad de la (re)presentación teatral一, a la vez que del innovador concepto de imitación del xviII: de ahí que este trabajo tome en consideración propuestas europeas como las de Diderot - la novela como drama extenso- o los panoramas franceses de costumbres. Se relaciona asimismo a Mesonero con la ambición abarcadora de los novelistas coetáneos. De esta contextualización se deriva una mejor comprensión no sólo de las aspiraciones de Mesonero, sino también del sistema de géneros miméticos, del proceso que conciliaba lo particular con la ambición de totalidad, y de la intensa mirada «realista» del escritor capaz de «leer» el mundo.

Palabras clave: Novela - teatro - costumbrismo - mímesis - realismo - siglos XVIII y XIX - Diderot - Mercier - Mesonero.

\section{SUMMARY}

Mesonero presented his articles relating them with bordering genres: the novel and the theatre. His discourse echoed the traditional Aristotelean opposition epic/tragedy - transformed in extension of novel and intensity of dramatic (re)presentation- and, at the same time, the innovating concept of imitation in the 18th century: thus, this paper takes into consideration the European proposals such as Diderot's - the novel as extensive dramaor the French panoramas of customs. Likewise, this article relates Mesonero to the wide ambition of contemporary novelists. A better comprehension is derived from this contextualization, not only of his aspirations, but also of the system of mimetic genres, of the process that unites the particular with the ambition of the whole, of the writer's intense outlook «realist» able to «read» the world.

Key words: Novel - theatre - literature of manners - mimesis - realism - 18th and 19th centuries - Diderot - Mercier - Mesonero. 